\title{
35. LOWER CRETACEOUS LITHOSTRATIGRAPHY NEAR GALICIA BANK
}

\author{
V.A. Basov, B.G. Lopatin, I.S. Gramberg, A.I. Danjushevskaya, V.Ya. Kaban'kov, V.M. Lazurkin, \\ and D.K. Patrunov, \\ Research Institute of the Geology of the Arctic, Scientific and Technical Complex "SEVMORGEO," \\ Leningrad, USSR
}

\section{INTRODUCTION}

This report deals with results of the first stage of a complex study of the predominantly Lower Cretaceous sediments cored at Site 398 at depths from 945 to 1740 meters. The section studied is overlain by 35 meters of Cenomanian sediments, which are similar lithologically to the underlying sequence.

We studied 370 samples using the same methods as described in our chapter in Volume 47, Part 1. The main goal is to define more precisely the stratigraphy of Lower Cretaceous sediments and provide some tentative conclusions on evolution and environmental conditions of the depositional basin.

Lithology and mineralogy were compiled by V.Ya. Kaban'kov, B.G. Lopatin, and D.K. Patrunov; biostratigraphy by V.A. Basov; clay minerals by V.M. Lazurkin; geochemistry of clays by I.S. Gramberg; and organic matter by A.I. Danyushevskaya. The conclusions were written jointly and edited by B.G. Lopatin.

\section{LITHOLOGY AND MINERALOGY}

Lithologic units: We recognized three major lithologic units within the Lower Cretaceous (plus Cenomanian) sequence. Upper Unit 3 is divided into Subunits a, b, c, and d, each being gradational to one another. The lower unit (1) corresponds to Unit 5 of the Shipboard Summary and Unit 2 corresponds to the lower part of Unit 4c. The contact between our Subunits $3 \mathrm{a}$ and $3 \mathrm{~b}$ is close to the contact between Sub-units $4 \mathrm{c}$ and $4 \mathrm{~b}$. Finally, the boundary between our Sub-units $3 \mathrm{c}$ and $3 \mathrm{~d}$ is close to that of Sub-units $4 \mathrm{a}$ and $4 \mathrm{~b}$ of this summary. In summary, our lithostratigraphic column does not differ much from that of the shipboard scientists. As usual, the lithostratigraphic and biostratigraphic boundaries are not coincident (Figure 1).

\section{Unit 1}

Unit 1 (Cores 138 and 130) is of Hauterivian(?)Barremian age and is composed mainly of massive or laminated pelitomorphic limestone with varying amounts of clay and silt. The limestone is interbedded with thinly laminated calcareous-clayey siltstones. Brecciated structure in the limestone is common as a result of slumping, deformation or partial scour and redeposition of calcareous clays. Silt-sized fragments of quartz, feldspar, and muscovite are common, along with carbonate clasts.
The limestones are usually pigmented by numerous opaque plant fragments, partly replaced by fine-grained pyrite or hydrous ferric oxides. Clay minerals comprise thin lenticular lamina wherein the remains of nannofossils are obvious. A nannofossil origin for the massive dense limestone may be deduced from this observation. Some intervals contain large amounts of silt-size calcite grains recrystallized into fine-grained aggregates. The limestone contains ubiquitous pelecypod(?) fragments oriented along bedding. Foraminifers and radiolarian tests are often concentrated in separate layers. Part of the calcite grains are of terrigenous origin. Frequent layers of terrigenous pebbles 1 to $2 \mathrm{~cm}$ in thickness are usually confined to clayey limestone which are also enriched in other clastic material. Siltstone and fine-grained sandstone consist of quartz, feldspar, and muscovite with subordinate amounts of biotite. Clastic carbonate is abundant in some layers. Terrigenous rocks are cemented by fine-grained calcite or clayey calcareous pelitic material with remains of nannofossils. Some layers are rich in hydrous ferric oxides, presumably the result of biotite decay.

\section{Unit 2}

Unit 2 (Cores 129 to 116 ) belongs to the upper Barremian and part of the Aptian. It consists mainly of terrigenous rocks of differing origins: limestone pebble debris flows; mud-supported conglomerates; and turbiditic mudstones, siltstones, and sandstones. Debris flow sediments are poorly sorted and composed of angular to angular-rounded clasts up to 3 to $4 \mathrm{~cm}$ in diameter. These consist of light colored limestone, marly limestone massive or bedded, and mudstone. Nannofossil limestone clasts (angular and rounded) are common ranging to 10 per cent of the whole rock. Macrofauna and microfauna tests are also present as fragments. The composite composition of some clasts (Plate 1) provides evidence for recurrent scour of the already formed flow sediments. Limestone pebbles have the same appearance as the limestone within Unit 1.

Coarse-grained rocks are interbedded with finegrained clayey terrigenous and clayey calcareous sediments. Calcareous material is usually of nannofossil origin.

Turbiditic fine-grained sandstones, siltstones, and mudstones have wavy and cross-laminated structures indicating high dynamic sedimentation conditions. In- 


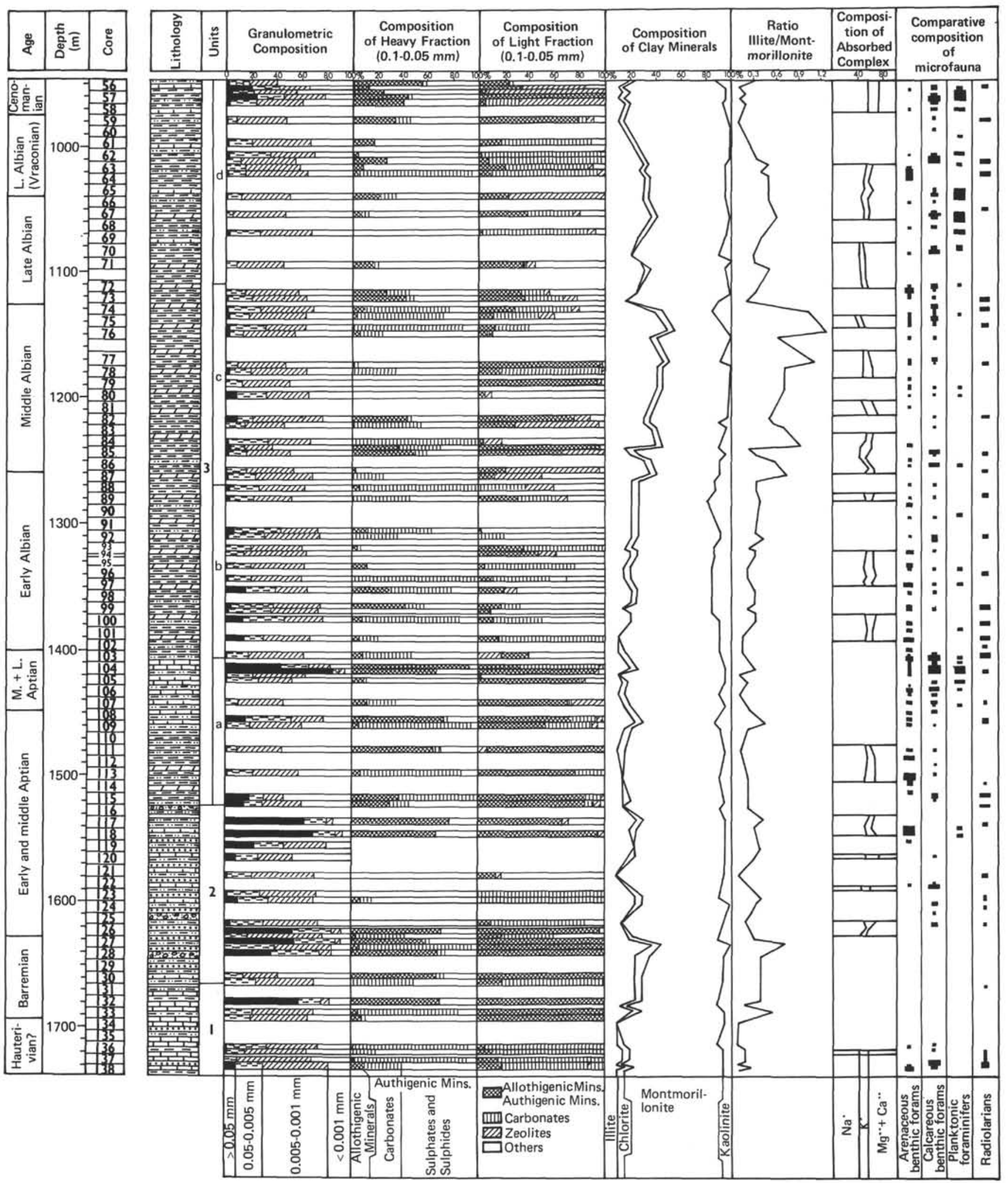

Figure 1. Summary chart of the Lower Cretaceous section of Hole 398D. 
terbedded, thinly laminated, flat-bedded, fine-grained rocks reflect fluctuating water conditions.

The terrigenous material consists of quartz and feldspar (to $50 \%$ and more), muscovite (to $15 \%$ ), and biotite (to $3 \%$ ). Of the feldspars, sodic types are strongly dominant.

Some layers are enriched in detrital organic matter. Clastic material is cemented by calcareous clay containing hydrous ferric oxides and spots of poorly recrystallized silica.

Zeolites are a ubiquitous authigenic mineral in the terrigenous rocks. It usually fills in radiolarian tests and is less common as $0.1 \mathrm{~mm}$ prismatic crystals distributed within a calcareous clay matrix. According to X-ray data, the zeolites belong to the heulandite group and are probably clinoptilolite, based on their low refractive index (1.475 to 1.480$)$.

The rock matrix consists of flaky aggregates of mainly illite-montmorillonite and carbonate represented by nannofossils. Radiolarian tests are common and comprise up to 15 per cent of the rock.

\section{Unit 3}

Unit 3 is characterized by its more uniform and clayey composition. It represented the so-called "black claystone formation."

Sub-unit 3a (Cores 115 to 103) of middle and late Aptian age is composed of dense clays and silty clays with subordinate silt and fine-grained sandstone layers. The clays and silty clays consist mainly of flaky clay minerals with admixtures of silt-sized grains of quartz, sodic feldspar, and muscovite, with nannofossils in highly variable amounts. In the lower part of the interval (to Core 111), nannofossils are $<1$ per cent; further uphole, their content increases to 20 per cent. The top of the sub-unit (Cores 106 through 103) is composed of marly nannofossil limestone showing slump and brecciated structures. In the clayey sediments, nannofossils occur in thin lens-shaped lamina. In thin sections of marly limestones, we observed clasts of the same composition having sharp or obscure contacts with the surrounding rock. Foraminifers and radiolarians are common in clays and silts; their tests are often filled by zeolites.

Sub-units $3 \mathrm{~b}$ (Cores 103 to 88 ) and $3 \mathrm{c}$ (Cores 87 to 71 ) are differentiated on the basis of a change in the illite/montmorillonite ratio (Figure 1). Sub-unit $3 \mathrm{~b}$ comprises nearly all of the lower Albian interval, and Subunit $3 \mathrm{c}$ covers most of the middle Aptian interval. The lithology of these sub-units is rather monotonous; dark gray, dense clay, and silty clay predominate. Within Sub-unit $3 \mathrm{~b}$, thin terrigenous layers of silt and finegrained sandstone are relatively common. Major clastic minerals are quartz, feldspar, muscovite and biotite, foraminifers, and radiolarian tests. In some intervals (Samples 398D-104-1, 55 to $58 \mathrm{~cm}$ and 398D-98-2, 34 to $43 \mathrm{~cm}$ ), there is an abundance of stable accessory minerals such as tourmaline, garnet, zircon, and opaques.

At Core 91, clay minerals acquire well-defined aggregate texture and oriented extinction. This pattern of clay minerals texture can be noted up to Core 62 . We observed the same texture within Lower Cretaceous sediments at Site 397.

The inclusion of biotite relics occasionally in illite aggregates of brown and brown-greenish color indicates that illite diagenetically replaced clastic biotite.

Hydrous ferric oxides and nannofossil accumulations in thin lamina are widespread.

In addition to calcareous carbonate of biogenic origin, we noted microscopic aggregates and separate rhombohedral crystals of ferruginous carbonates with refractive index $>1.78$. These carbonates form numerous light-colored laminae, lenticles, and nodules within Unit 3 and are especially abundant within Sub-units $3 b$ and $3 \mathrm{c}$. Composition of this carbonate, identified as dolomite aboard ship, is complex and described later.

Within Sub-units $3 \mathrm{~b}$ and $3 \mathrm{c}$, heulandite is widespread. It fills microfauna tests and also occurs as separate crystals and aggregates in the clay matrix. Euhedral prismatic crystals with low refractive index $\left(\mathrm{N}_{1}=1.470 ; \mathrm{N}_{2}=1.480\right)$ probably is clinoptilolite.

Sub-unit 3d (Cores 71 to 56) of late Albian and Cenomanian age has predominantly a clayey composition with terrigenous material increasing slightly upsection (Figure 1). Its lithology differs from the underlying sub-units by lesser amounts of the aforementioned complex carbonate, by the increasing role of calcareous material, and by a higher content of zeolites. We noted two main morphological types of zeolites: (1) wellshaped crystals in microfauna, mainly radiolarian tests (Plate 2, Figure 1), and (2) fine-grained aggregates with crystalline texture detectable only under high magnification (Plate 2, Figures 2 to 4).

Mineralogical summary: We studied the mineral composition of 84 samples in the 0.1 to $0.05 \mathrm{~mm}$ grainsized fraction. All the minerals can be roughly divided into two groups: (1) terrigenous minerals (including cosmic particles) and (2) biogenetic and chemogenic minerals.

\section{Group 1}

Up to 30 different species of heavy minerals occur, although the average sample contains approximately 20 specimens. Stable minerals predominate, such as tourmaline, garnet, zircon, staurotite, andalusite, sillimanite, spinel, and opaques. They are rounded or angular rounded. Less stable minerals (pyroxenes, amphiboles, epidote, sphene, rutile, brookite, anatase, leucoxene, kyanite, chloritoid, orthite, and apatite) are not as abundant and only occur sporadically.

We found 14 minerals in the light fraction, but quartz (50 to $60 \%$ ) and feldspar (15 to $20 \%$ ) strongly predominate. The light fraction contains rock fragments and compound mineral aggregates.

Persistent allochthonous stable heavy minerals indicate a tectonically inactive source area with a climate favorable for intensive chemical weathering. Apparently, the source area was composed mainly of metamorphic rocks. 


\section{Group 2}

Minerals of the second group include carbonates, zeolites, phosphates, hydrous ferric oxides, pyrite, remains of siliceous organisms, and barite. These minerals are mainly of diagenetic origin. Ferromanganese carbonates, pyrite, and hydrous ferric oxides predominate within the heavy fraction. Pyrite sometimes is 80 per cent of the heavy fraction and, in most cases, replaces organic detritus. Phosphates are of organic origin and occur throughout the entire sequence. Barite is not as frequent but is scattered throughout all sections.

The light fraction consists of biogenic carbonate and silica and zeolites. The refraction index of radiolarian tests is 1.46 to 1.47 . Spicules are opaline.

Analyses of carbonates: The mineral composition of the carbonates was established petrographically. Eight sample analyses in the VSEGEI (Leningrad) laboratories used thermobalance (Unit UTA-1, Analyses by B.K. Kasatov), and X-ray methods. Thermobalance analyses were corrected for $\mathrm{CO}_{2}$ per cent contents in selected samples. Analyses of hydrochloric extracts (12 samples) and acetic extracts (27 samples) of carbonate clay rocks were performed in the "Sevmorgeo" laboratory. These results were used for studies of ferrous and manganous carbonate distribution throughout the section.

A major rock-forming carbonate mineral in much of the section is calcite, often with distinct structural features indicative of a biogenic origin (nannofossils, skeletal detritus) and diagenetic recrystallization. Unit 3 is characterized by abundant authigenic minerals represented mainly by siderite and manganese-bearing carbonate minerals. Rhodochrosite, however, is usually absent. There is also evidence of a small amount of a carbonate mineral similar to ankerite. A widely developed isomorphism mainly in a calcite-siderite-rhodochrosite series is a common feature of the carbonate minerals.

Siderite in Cores 102 to 71 forms numerous bands and lenses. These are yellowish and were described aboard ship as dolomite. Even more abundant siderite was found analytically in thin sections. In Section 126-6, siderite intensely replaces a semi-opaque pelitic mass containing fragments of calcareous rock.

In Cores 102 to 88 (Unit 3) layers with high abundances of siderite are up to $2 \mathrm{~cm}$ thick. They diverge in places and form a complex pattern with enclosing clay sediments. In Cores 97 to 95 , similar formations were observed growing on fragments of mollusk shells. Siderite at this level is characterized by a porous spongy structure and wavy lamination.

Siderite crystals (up to $0.1 \mathrm{~mm}$ ) occur in Unit 3 and are easily seen in thin sections. Dense laminated segregations of euhedral siderite were studied in thin sections from Cores 93, 89, and 88. Siderite in Section 93-3 also was examined under the scanning microscope (Laboratory of the Botanical Institute, Leningrad).

Concentrations and the size of siderite crystals change from layer to layer. Separate laminae consist of large $(0.1 \mathrm{~mm})$ more or less scattered euhedral siderite crystals (Plate 3, Figure 1). In some laminae, they form growths. Such laminae (up to $0.5 \mathrm{~cm}$ thick) grade into laminae of a dense aggregate of euhedral siderite. As this gradual transition occurs both downwards and upwards, the combined siderite laminae form a symmetrical graded bedding. Large siderite crystals occur in a dark brown, almost opaque matrix. It is apparently a pelite with a high admixture of dispersed organic matter. On some micrographs with large magnification, crystals are surrounded by very thin threads (Plate 3, Figure 3), which are possibly scraps of organic tissue.

Very distinct siderite crystals have rhombohedral outlines, however their facies are slightly convex and bent. Crystals are peculiarly fissured along cleavage. On scanning microscope photographs, such crystals appear as a package of plates. Flaky overgrowths on crystal facies (Plate 3, Figure 4) confirm the authigenic nature of the siderite.

Differential thermal analysis of a sample of euhedral siderite shows clear peaks corresponding to this mineral. On thermograms of samples taken above Core 88 (Unit $3 \mathrm{c}$ ), peaks are dim and not as strong (Figure 2), and the siderite occurs mainly as a very thin interval that is poorly discernible in a thin section. Obviously, the crystal lattice in such segregations is imperfect, i.e., siderite is represented by crystal embryos.

The siderite distribution shows a direct correlation with the concentration of organic matter in predominantly clayey pelites.

Siderite is known to be a characteristic diagenetic mineral produced in sediments under highly reducing conditions, high $\mathrm{CO}_{2}$ partial pressure, and low calcium carbonate content (Timofeeva, 1963; Stashchuk, 1973). The iron necessary to produce siderite is supplied apparently absorbed on pelite particles.

Manganese occurs in the form of an isomorphic admixture to carbonate minerals, in particular, to diagenetic siderite. There is a correlation between manganese content in the isomorphic admixture and ferrous carbonates. At the same time, a very high manganese content was determined using acetic extracts in some carbonate-clay rocks, e.g., 12.78, 10.37, and 3.17 per cent in Sections $72-1,86-3$, and 81-4, respectively (evaluated for $\mathrm{MnO}$ content). Based on these analyses, it appears that the manganese in these cores occur either in an absorbed state on pelite particles or as segregations. We suggest that manganese entering a lattice of carbonate minerals (and in some cases crystallization in the form of rhodochrosite) is a diagenetic process. The presence of free manganese in a reducing medium, one of the environments favorable for the production of manganese carbonates, fostered this process (Bencini and Turi, 1974).

Clay mineral analyses: We studied the composition of clay minerals using X-ray analysis of 84 samples of clay rocks. Fractions $<0.005 \mathrm{~mm}$, amounting to 60 to 90 per cent of the rock, were used for the analyses. The analyzed samples are uniformly distributed throughout the section (Appendix A).

$\mathrm{X}$-ray studies were carried out on a diffractometer DRON-1. Analytical error is 10 per cent.

Throughout the entire Lower Cretaceous section, clay minerals are represented by montmorillonite ( 40 to 


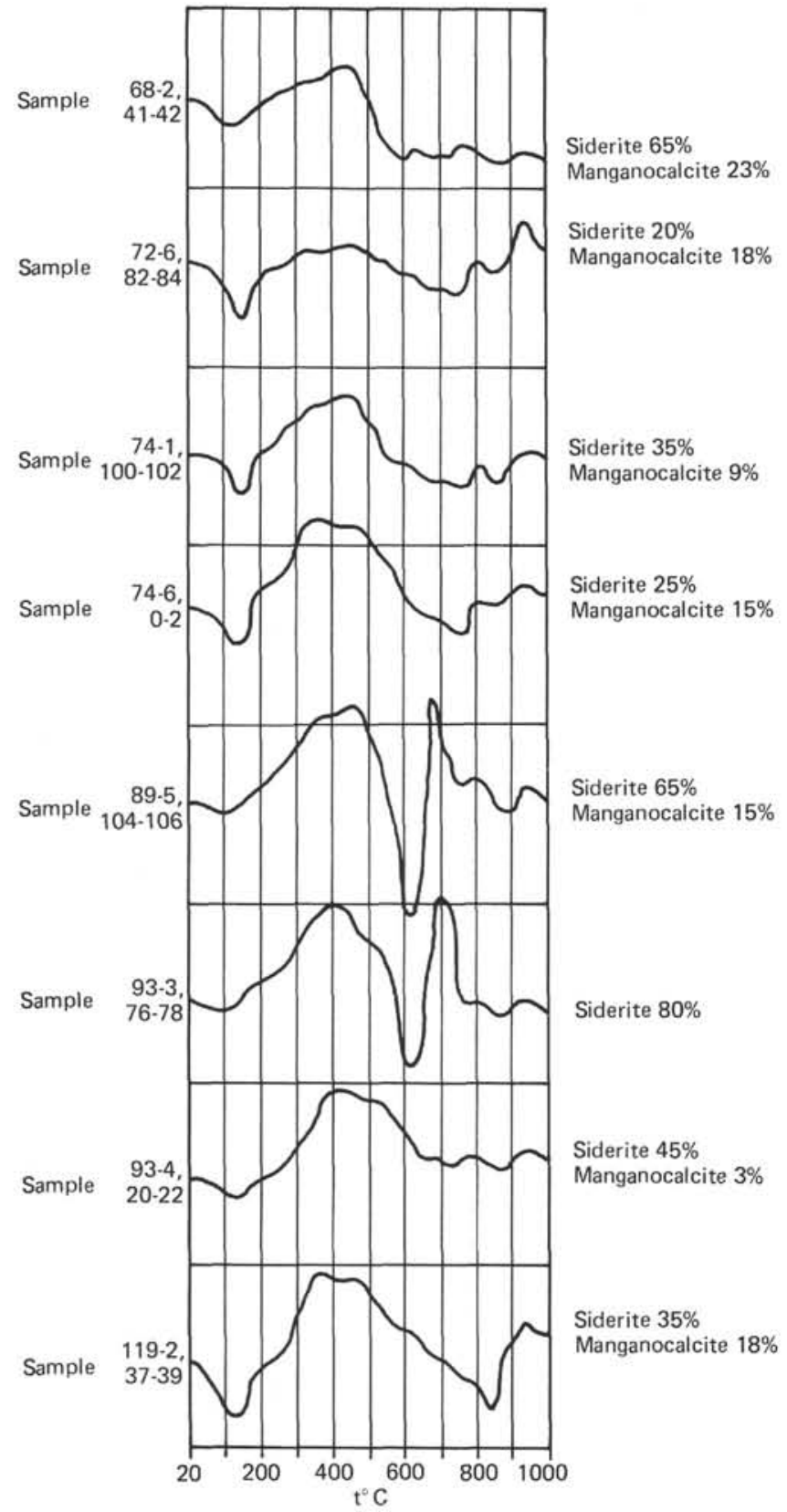

Figure 2. Thermograms of ferromangano carbonates Hole $398 D$.

$85 \%$ ), illite (10 to $50 \%$ ), kaolinite ( 0 to $20 \%$ ), and chlorite ( 0 to $10 \%)$.

Examining the clay mineral distribution suggests that similar abundances are related to certain intervals coinciding approximately with the established lithostratigraphic units. To illustrate this distribution, we used an illite-montmorillonite ratio as the most variable value. The abundance of chlorite and kaolinite is relatively constant (except for a high kaolinite content in the lower Albian deposits) throughout the section. We identified five intervals using this ratio (Table 1). The kaolinite content is three times higher in the lower Albian than in the older parts of this section.
At this stage of our studies it is difficult to establish the cause for the changes in the illite-montmorillonite ratio because it depends on many factors. In our opinion, it is mainly due to changes in the sedimentary environment. Our preliminary conclusions are as follows:

1) A maximum content of montmorillonite and minimum content of illite in the Hauterivian sediments (Unit 1) possibly implies relative nearness to a source area. An illite increase up-section suggests a somewhat deeper basin.

2) In the Aptian and especially in the early Albian (Unit 2 and Sub-units $3 a$ and $3 b$ ), the environment again was similar to that of the Hauterivian; however, new source areas appeared and provided larger amounts of kaolinite.

3) We suggest that during the middle and early late Albian (Unit 3c), sedimentation took place in a typical deep marine basin based on a maximum illite content. Another environment change began at the end of the Early Cretaceous (Sub-unit 3d).

Geochemistry of the clay rocks: The Lower Cretaceous clay rocks were studied geochemically. The composition of absorbed cations was determined in 48 samples and the composition of difficulty soluble components was studied in 27 (partly grouped) samples.

Absorbed cations $\left(\mathrm{NA}^{+}, \mathrm{K}^{++}, \mathrm{Mg}^{++}, \mathrm{Ca}^{++}\right.$) were determined in an ammonium chloride extract, the easily soluble salts being first washed in a 60 per cent water-alcohol solution.

The composition of the absorbed cations is indicative of marine environments (Appendix B). Sodium is dominant, amounting to 50 to 58 per cent equivalents in twothirds of the samples. The content of potassium in the absorbed complex varies from 4 to 20 per cent equivalents; in three-fourths of the samples, it accounts for $>10$ per cent equivalents.

The Hauterivian-Barremian deposits of Unit 1 are characterized by lower values for the sum of absorbed cations. A wide range of potassium content (from 4 to $17 \%$ equivalents) is a peculiar feature of this part of the section. Potassium content is minimal in Samples 126-6, 70 to $80 \mathrm{~cm}$ and $127-4,90$ to $100 \mathrm{~cm}$.

In Unit 2 and Sub-unit $3 a$, the sodium content is always high while that of potassium varies as shown by the sodium to potassium ratio ( 3 to 9 ). Magnesium amounts to about 50 per cent of the alkaline earth cations. The sodium content increases but slightly in the upper part of the Lower Cretaceous strata, reaching maximum in the Senomanian. The Senomanian has a large quantity of absorbed cations (up to $40 \mathrm{mg}$-equiv. per $10 \mathrm{~g}$ of rock). About one-half of the alkaline-earth cations is due to magnesium.

Components which are difficult to render soluble were studied using acetic extract. They were treated three times by a hot $1 \mathrm{~N}$ acetic acid (first treatment), and by $2 \mathrm{~N}$ acid to which the reducing agent metabisulfate was added (second and third treatments).

These components are represented mainly by calcium carbonate, the content of which is especially high in Cenomanian samples. In the lower part of the hole 
TABLE 1

Clay Mineral Stratigraphic Units

\begin{tabular}{|c|c|c|c|c|c|c|c|c|}
\hline \multirow[b]{2}{*}{ Unit } & \multirow[b]{2}{*}{ Age } & \multirow[b]{2}{*}{$\begin{array}{l}\text { Thickness } \\
\text { (m) }\end{array}$} & \multirow[b]{2}{*}{ Cores } & \multirow{2}{*}{$\begin{array}{l}\text { Number of } \\
\text { Analyzed } \\
\text { Samples }\end{array}$} & \multicolumn{2}{|c|}{$\begin{array}{c}\text { Average Content } \\
(\%) \\
\end{array}$} & \multicolumn{2}{|c|}{$\begin{array}{c}\text { Illite Mont- } \\
\text { morillonite Ratio }\end{array}$} \\
\hline & & & & & Illite & $\begin{array}{l}\text { Mont- } \\
\text { morillonite }\end{array}$ & & \\
\hline 1 & $\begin{array}{l}\text { Late Albian- } \\
\text { Cenomanian }\end{array}$ & 180 & 56 to 73 & 18 & 22 & 65 & 0.34 & $\begin{array}{l}0.1-0.6^{\mathrm{a}} \\
(0.2-0.5)\end{array}$ \\
\hline 2 & $\begin{array}{l}\text { Middle-late } \\
\text { Albian }\end{array}$ & 135 & 74 to 86 & 14 & 35 & 53 & 0.66 & $\begin{array}{l}0.2-1.25 \\
(0.5-1.0)\end{array}$ \\
\hline 3 & $\begin{array}{l}\text { Aptian-early } \\
\text { Albian }\end{array}$ & 370 & 87 to 126 & 37 & 18 & 69 & 0.26 & $\begin{array}{l}0.1-0.45 \\
(0.2-0.3)\end{array}$ \\
\hline 4 & Barremian & 65 & 127 to 133 & 7 & 27 & 62 & 0.44 & $\begin{array}{l}0.2-0.7 \\
(0.4-0.6)\end{array}$ \\
\hline 5 & Hauterivian(?) & 45 & 133 to 138 & 8 & 13 & 77 & 0.17 & $\begin{array}{l}0.1-0.3 \\
(0.1-0.2)\end{array}$ \\
\hline
\end{tabular}

${ }^{\mathrm{a} C o m m o n}$ values.

(Hauterivian-Barremian), $\mathrm{CaO}$ accounts for 70 to 80 per cent of the whole content of oxides (Appendix C).

Magnesium content is not high relative to that of calcium, but the highest absolute content is associated mainly with calcium-rich parts of the section. Titanium compounds in the acetic extract were not found.

The deposits of Hole 398D are characterized by a high manganese oxides to magnesium ratio; for only six samples it is <10. Samples 398D-72-1, 141-143 cm and $398 \mathrm{D}-86-3,80-82 \mathrm{~cm}$ stand apart, where $\mathrm{MnO} / \mathrm{MgO}$ is 2017 and 1637, respectively. Samples 398D-87-4, 113$115 \mathrm{~cm}$; 398D-81-2, 23-25 cm; 398D-81-4, 103-105 cm; and $398 \mathrm{D}-97-1,31-33 \mathrm{~cm}$ are also characterized by high manganese to magnesium ratio, i.e., 662,310, and 176. We also found high contents of $\mathrm{Al}_{2} \mathrm{O}_{3}, \mathrm{Al}_{2} \mathrm{O}_{3}$ and $\mathrm{SiO}_{2}$, and $\mathrm{FE}_{2} \mathrm{O}_{3}$ and $\mathrm{Al}_{2} \mathrm{O}_{3}$ in these carbonaceous rocks.

Sedimentation of Cretaceous deposits of Hole 398D took place in a marine basin with a salt composition similar to that of Recent marine water. Like Recent sediments, the absorbed complex for Lower Cretaceous clay rocks is characterized by a high content of alkaline elements where sodium greatly predominates. Alkaline earth elements have a relatively high magnesium content.

Difficultly soluble components (acetic extract) are characterized by an unusually high (up to 10 to $12 \%$ ) manganese content in samples of Aptian-Albian age, obviously due to its intense transport form the continent.

\section{BIOSTRATIGRAPHY}

Lower Cretaceous sediments in Hole 398D (975 to 1740) m) contain different microfossils among which benthic foraminifers and radiolarians are the most variable (Figure 3). Planktonic foraminifers (the most important group for age determination) occur sporadically and become diverse and most abundant in the uppermost part of the section. This group, which was determined by Dr. T.N. Gorbachik, allows the establishment of several stratigraphically important levels. These levels are useful in the recognition of the upper Aptian by the mass occurrence of Hedbergella trochoidea (Cores 105 and 104), separation of upper Albian (Vraconian) by the appearance of Thalmanninella ticinensis (Core 65), and determining the location of the Senomanian boundary by the appearance of Thalmanninella appenninica (Section 58-2).

Another important group of planktonic organism was radiolarians, as determined by Dr. G.E. Kozlova (Figure 4). They form mass accumulations in many samples taken from different parts of the section. The oldest radiolarian assemblage was found in Sections 137-3 and 136-3. It consists of poorly preserved molds and pyritized skeletons allowing the establishment of some species characteristic of the Sethocapsa trachyostraca Zone. On the basis of data obtained during DSDP Leg 32 (the northern Pacific), this zone was assigned by Foreman (1975) to the Valanginian-Barremian, while Riedel and Sanfilippo (1974) assigned similar deposits in the Atlantic Ocean to the ValangianHauterivian.

Section 130-4 contains some poorly preserved skeletons suggesting the presence of Eucyrtis tenuis; Cores $121,118,117$, and 116 have a radiolarian assemblage characteristic of this zone. According to Foreman, the upper boundary of this zone extends beyond the lower Aptian, but W. R. Riedel and A. Sanfilippo assigned this zone to the Barremian-Albian. We noted Alievium antiquum Pessagno typical of the Aptian in the upper part of this zone (Cores 117 and 116).

Samples from Cores 115 to 99 contain a rich assemblage of radiolarians including more than 30 species characteristic of the Acaeniotyle umbilicata Zone assigned by Foreman to the Aptian-Albian.

Some samples from Cores 96 to 88 contain scarce radiolarians. In this section, we found a few species of Hagiastridae as well as several nasselarians with a predominance of Holocryptocanium barbui Dumitrică. The zonal position of this assemblage in a local section is not clear.

Samples from Cores $73,67,63,62$, and 59 contain a radiolarian assemblage typical of the Dictyomitra somphedia Zone. Rhopalosyringium, Theocampe, and other Late Cretaceous forms, e.g., Amphiptermis alamedaensis (Campbell and Clark), Spongotripus morenoensis (Campbell and Clark), Stichomitra (?) cechena Foreman appear in the upper part of the section.

Foreman (1975) assigned Dictyomitra somphedia Zone to the upper Albian-Turonian. A radiolarian 


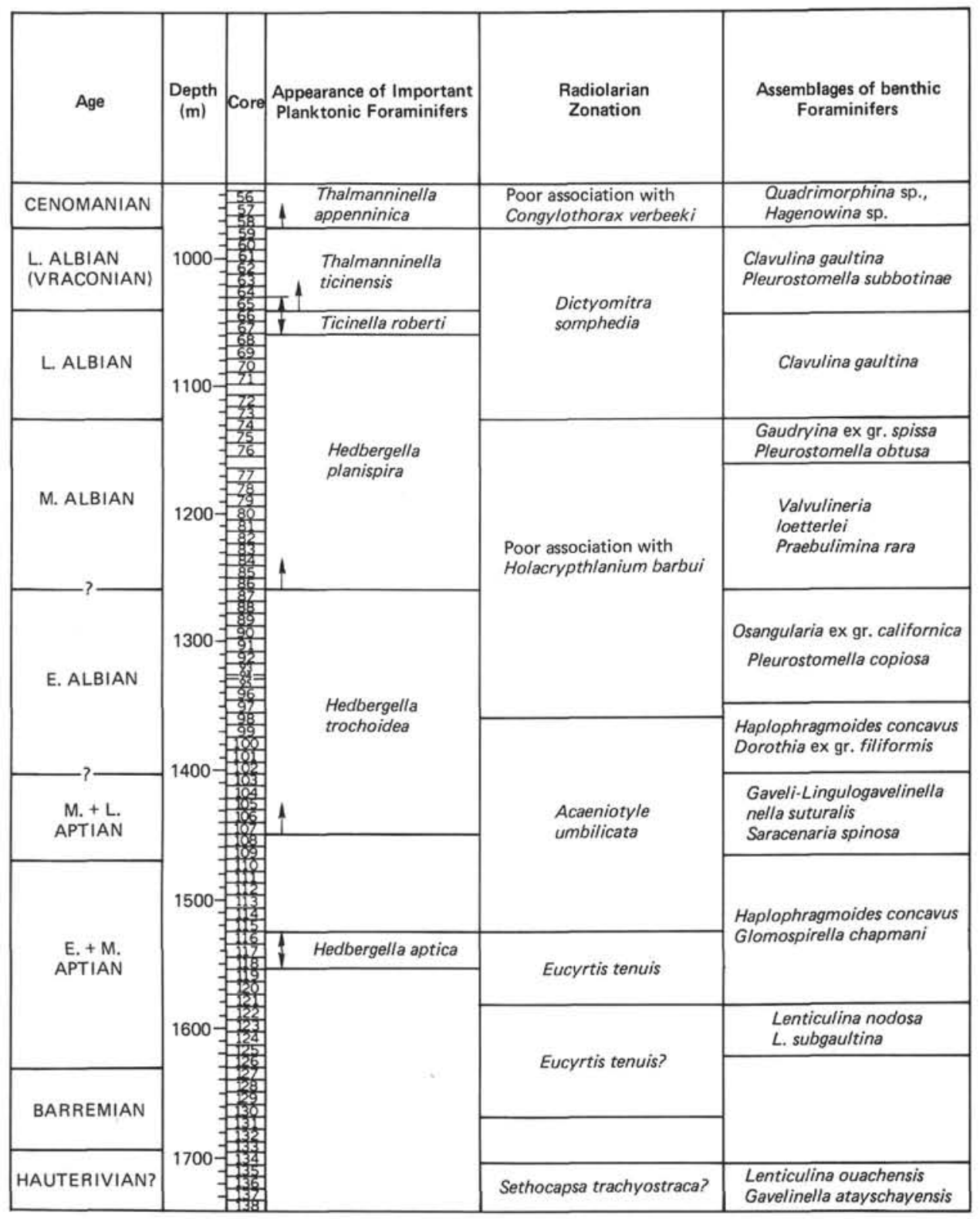

Figure 3. Important foraminiferal assemblages and radiolarian zones in the Lower Cretaceous sequence of Hole 398D.

assemblage from this zone in Hole $398 \mathrm{D}$ is very similar to the late Albian fauna of northeastern Azerbaijan (the Greater Caucasus) described by Aliev (1965).

A sample from Core 56 contains only several species including Gongylothorax verbeeki Tan Sin Hok. The age is indeterminable.

On the basis of radiolarians, it is possible to recognize the Neocomian (the Sethocapsa trachyostraca Zone, apparently not younger than Hauterivian and the lower Eucyrtis tenuis Zone, most probably of Barremian age), Aptian (the upper E. tenuis Zone), AptianAlbian (the Acaeniotyle umbilicata Zone) and upper Albian deposits (the Dictyomitra somphedia).

These data show a good correlation with those for planktonic foraminifers and additionally make it possi- ble to outline the scope for almost all the stratigraphic units of the Lower Cretaceous.

Benthic foraminifers are the most variable and persistent group of microfossils in the section. About 110 species belonging to 51 genera and 22 families were identified from the Lower Cretaceous sediments (Figure 5). Species of the following families predominate: Ataxophragmiidae, Nodosariidae, Osangulariidae, and Anomalinidae.

The Lower Cretaceous benthic foraminifers of Hole 398D are the richest fauna of this age in the Atlantic. They deserve more thorough study. The fauna discussed are very similar to the Lower Cretaceous foraminifers of the Caucasus. This allows comparison with a region for which correlation charts having been compiled for 


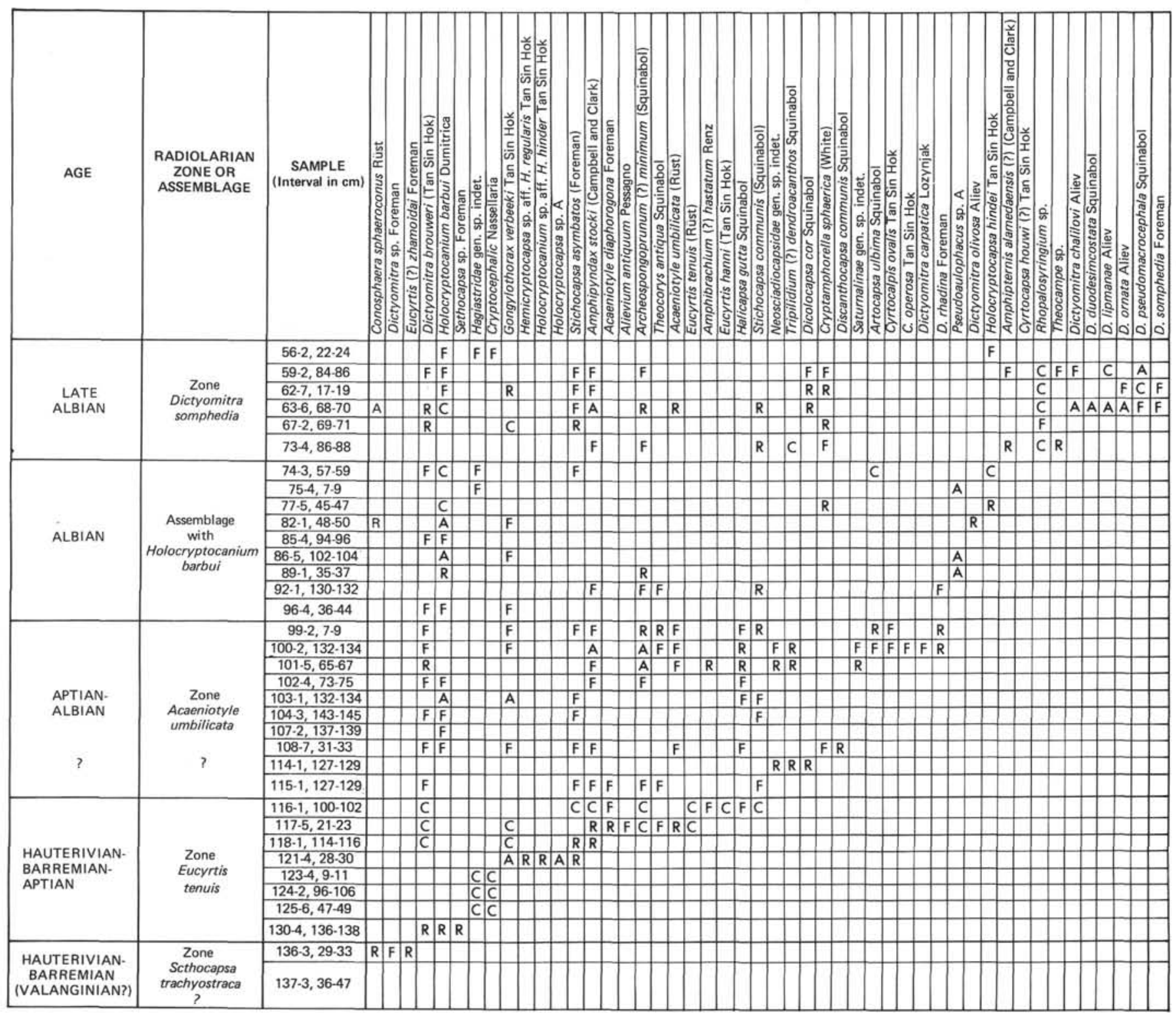

Figure 4. Distribution of radiolarians in the Lower Cretaceous section of Hole 398D.

several decades and for which the data for benthic and planktonic foraminifers distribution are consistent with those of ammonites.

The oldest deposits of the section studied yield an assemblage with Lenticulina ouachensis (Cores 137 and probably 136). In addition to an index species, it contains: Dorothia “ouachensis Moullade" (non Sigal), $D$. cf. trochus Orb., Pseudonasaria sp., P. humilis Roemer, Astacolus gratus (Reuss), Lenticulina aff. subgaultina Bartenstein, L. muensteri (Roemer), Gavelinella atatschayensis Pronina, and others. Most species have a wide stratigraphic distribution within the Neocomian. L. ouachensis occurs mainly in Hauterivian and Barremian deposits. Abundant in our samples Dorothia "ouachensis" is very similar to a form figured by Moullade (1966) from the upper Hauterivian of the Alps. Gavelinella atatschayensis appears in the Caucasus in the upper Hauterivian and is characteristic of the Barremian. On the whole, the assemblage discussed is similar to that of the Barremian and apparently cannot be older than late Hauterivian.

In the overlying deposits (Cores 135 to 127), benthic foraminifers were not found. A stratigraphic subdivision of this part of the section was made on the basis of preliminary data provided by Dr. Sigal (this volume): the lower boundary of the Barremian was drawn at Sample 398D-133-5, $60 \mathrm{~cm}$ and the upper boundary was placed between Cores 127 and 128 .

An assemblage with Lenticulina subgaultina and $L$. nodosa was recognized in samples from Cores 125 to 120. It mainly contains calcareous foraminifers: index species, Lenticulina macrodisca (Reuss), $L$. ex gr. roemeri (Reuss), L. subalata (Reuss), Pseudonodosaria appressa (Leoblich and Tappan), P. humilis (Roemer), 
Ps. sp., Astacolus schloenbachi (Reuss), Hoeglundina ex gr. caracolla (Roemer), H. ex gr. spinulifera (Reuss), $H$. cf. laticostata Antonova, Pseudolamarckina? ex gr. reussi (Antonova), Conorboides ex gr. hofkeri Bartenst. and Brand, Globospirillina clara Antonova, and Trocholina sp. On the whole, the assemblage is similar to those of the late Neocomian (nodosariids and Hoeglundina ex gr. caracolla predominate) and also contains some Aptian forms (L. subgaultina, Hoeglundina cf. laticostata). The specific composition of the assemblage, as well as the absence of gavelinella characteristic of the lower Aptian, allows correlation with an upper Barremian-lower Aptian assemblage of foraminifers known from the North Caucasus (Antonova et al., 1964).

From Cores 118 to 111 (there are no data on Core 119) the assemblage composition changes drastically and primitive agglutinated foraminifers become predominant. This boundary is undoubtedly related to a change in the depositional environment and is not of stratigraphic importance. This assemblage is characterized by the following index species: Haplophragmoides convavus Chapman and Glomospirella chapmani (Mjatliuk), abundant baculiform forms of the genera Bathysiphon, Rhabdammina as well as Saccammina lathrami Tappan, Hyperammina aptica Dampel et Mjatliuk, Hyperamminoides ex gr. barksdalei Tappan, Glomospirella gaultina (Berthelin), Ammodiscus ex gr. cretaceous (Reuss), and Glomospira corona Cushman and Jarvis, et al. In some layers (Sections 115-3, 115-1, 114-1, 112-4, and 111-1), we found stratigraphically more important, scarce, calcareous foraminifers, the specific composition of which is different relative to the underlying layers. We found Lenticulina among which were $L$. subalata and $L$. kugleri, and of special importance is the first appearance in this section of Gyroidinoides (Figure 6): G. ex gr. infracretacea (Morozova), G. mjatliukae (Antonova). In the Caucasus, first Gyroidinoides are known from the middle Aptian (Tsirekidze, 1971).

Higher in the section (Core 109 to Section 103-2), we recognized an assemblage with Gavelinella suturalis and Saracenaria spinosa. Besides index species and species survivers from the underlying beds, especially within the agglutinated foraminifers, we found: Petellina sp., Dentalina expansa Reuss, Astacolus tripleurus (Reuss), Lenticulina pulchella (Reuss), L. oligostegia (Reuss), Lingulina buddencanyonensis Dailey, Spiroplectinata spp., Eponides chalilovi Djaffarov, and E. ex gr. morani Tappan. New species as Gyroidinoides (sp. n., Core 108; sp. n., Core 109) and Gyroidinoides infracretaceous (Morozova) become abundant, and the first small Pleurostomella sp. appear.

The assemblage on the whole is undoubtedly enriched by young species; some of them occur mainly in Albian deposits (Eponides). Gavelinella suturalis is known from the Aptian in the southern regions of the USSR; a species Saracenaria spinosa belongs mainly to the upper Aptian. The first Pleurostomella usually also occurs in the upper Aptian.
In the uppermost part of the assemblage described (Samples 398D-104-2, 18-20 cm up to 398D-103-2, 38-70 $\mathrm{cm})$, new young forms appear: Lingulogavelinella sp., Pullenia sp., Praebulimina ex gr. nannina Tappan, and Verneuilina agalarovae Djaffarov (known only from Albian deposits). The placement of the boundary between the Aptian and Albian at the base of Core 104 seems to be inconsistent with the abundance of Hedbergella trochoides (Gand.) in Cores 103 and 104. This species is typical of the upper middle Aptian, (where it is a zonal species) and the upper Aptian, although it occurs in the Albian as well. Unfortunately, we have not found other planktonic species of foraminifers which could be used for a more precise placement of the Aptian/Albian boundary. At the top of Core 103, we see a drastic change in the content of foraminifers, i.e., there again appears depauperated assemblages of agglutinated foraminifers with Haplophragmoides concavus. This boundary may be tentatively considered as a boundary between stages. Most probably, the beds with Gavelinella suturalis and Saracenaria spinosa should be assigned to the upper Aptian; however, a precise definition of the boundary between the middle and upper Aptian as well as the boundary between the Aptian and Albian are difficult to define exclusively on the basis of benthic foraminifers.

An assemblage of agglutinated foraminifers found in Cores 102 to 98 is depauperized and, in addition to index species, also contains baculiform forms of the type present in the lower middle Aptian assemblage, as well as Glomospira corona Cushman and Jarvis, Trochammina glomerata Antonova, and Hormosina? kijastachensis Antonova. Taking into consideration the appearance of Albian forms in the benthos of the underlying beds and the undoubted Albian age of the overlying beds, we tentatively assign these to the Albian.

Up-section there is an increase in calcareous foraminifers. An assemblage with Osangularia ex. gr. californica and Pleurostomella copiosa was recognized in Cores 97 to 87. In addition to asangularians, this interval is characterized by Gyroidinoides infracretaceous Morozova, Gavelinella ex gr. rudis (Reuss), Planulina sp., Eponides wassoewici Djaffarov, and Pleurostomella reussi Berthelin. Assemblages of calcareous foraminifers in this part of the section are depauperized and alternate with agglutinated types. The age of the sediments could be Albian but, on the basis of its stratigraphic position, it is better considered as early Albian.

Higher, in Cores 86 to 77 , calcareous foraminifers are more abundant but they still alternate with beds yielding only agglutinated foraminifers. This assemblage contains Valvulineria loetterlei Tappan and Praebulimina rara (Bukalova). There are abundant Eponides wassoewici Djaffarov, Gyroidinoides paleovortex Djaffarov, and probably new species of Gyroidinoides at the base of the beds. We also found Nodosaria concinna Reuss, Lingulina loryi Berthelin, Gyroidinoides infracretaceous (Morozova), Osangularia infracretacea (Bukalova) and Neobulimina spicata (Bukalova). This assemblage is Albian and contains some new forms 


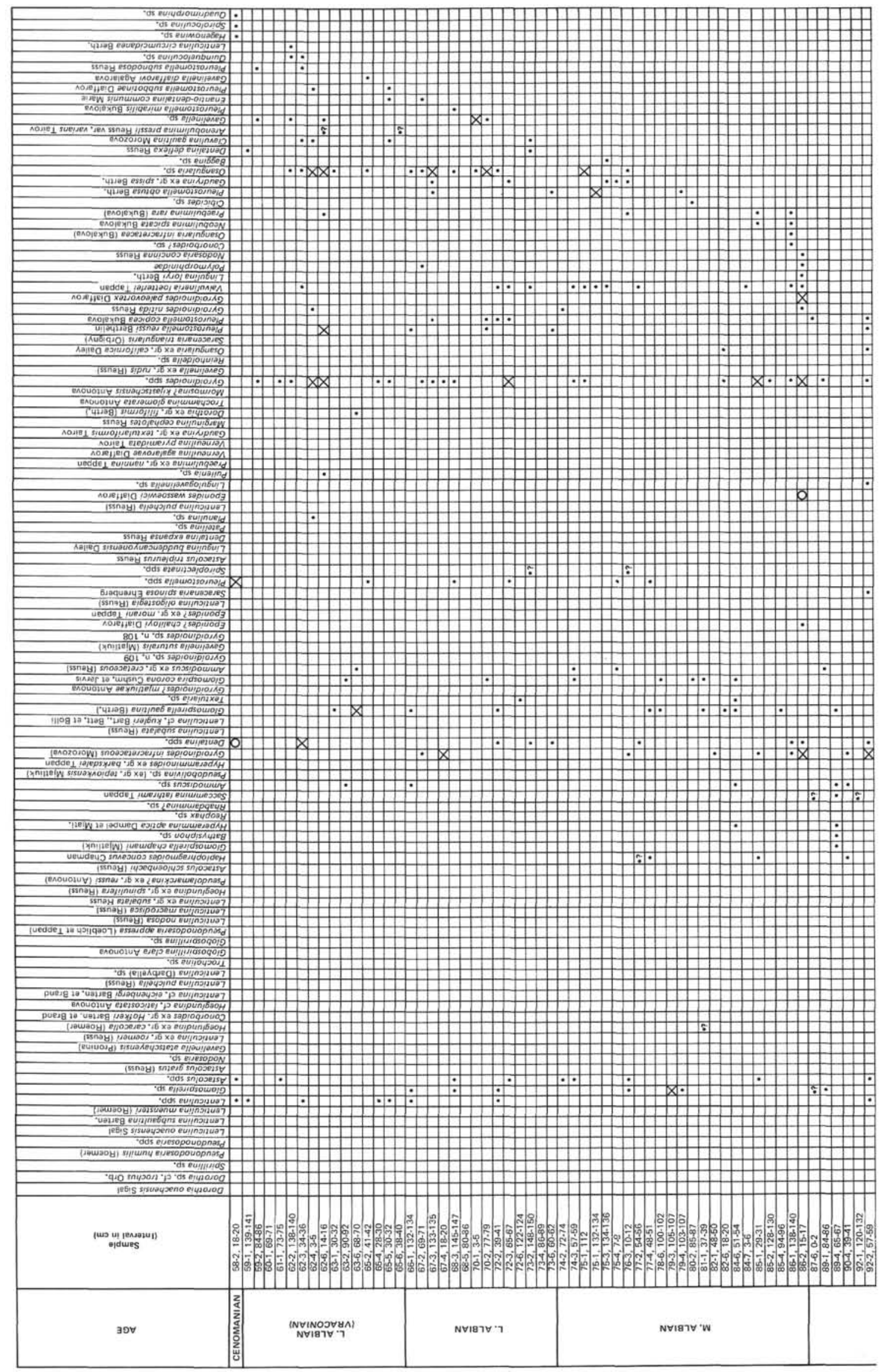




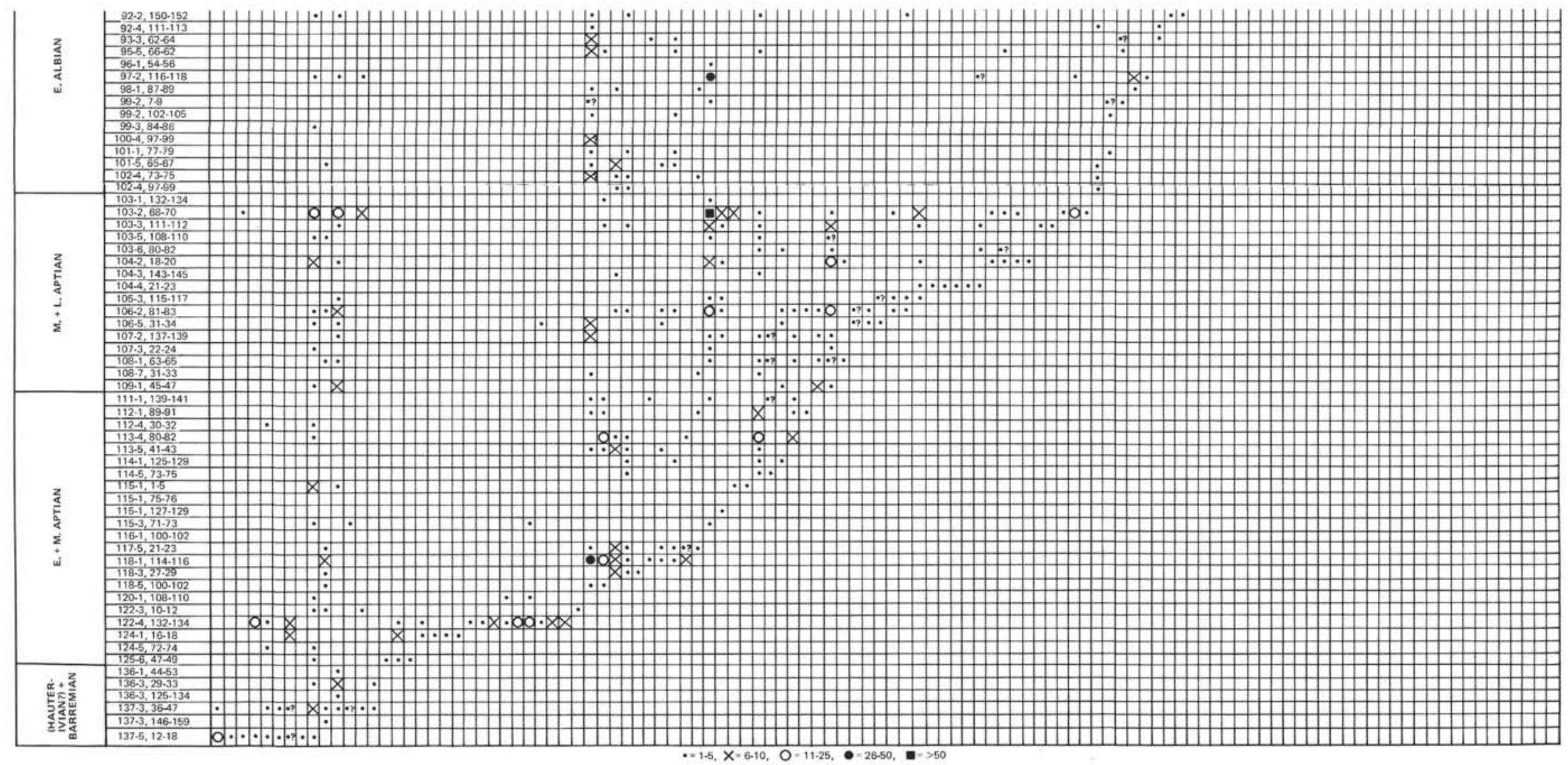

Figure 5. Distribution of benthic foraminifers in the Lower Cretaceous section of Hole 398D. 


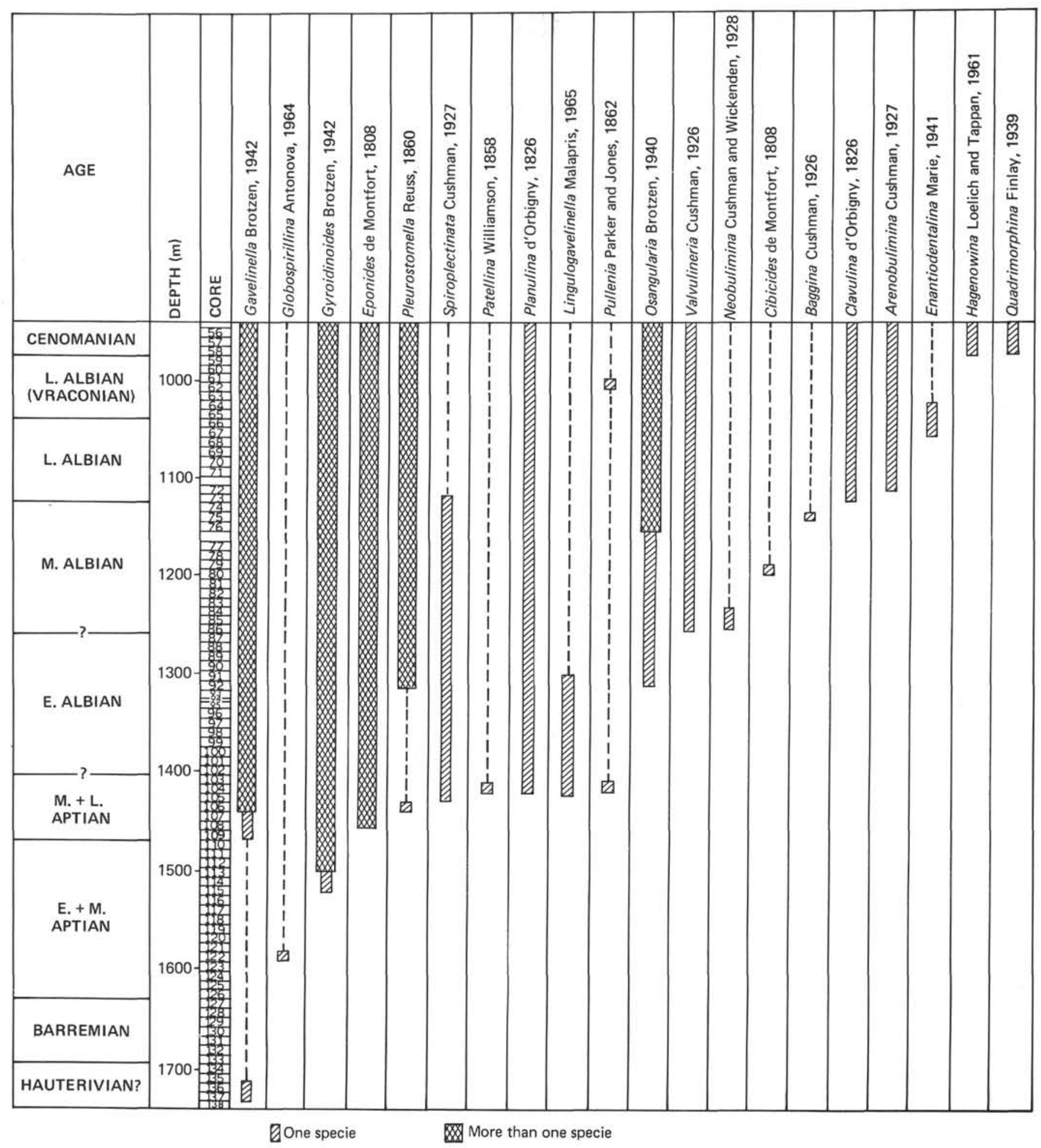

Figure 6. Distribution of benthic foraminiferal genera appearing in Early Cretaceous time.

which are characteristic in the Caucasus of the late Albian (buliminida). As Hedbergella planispira usually appears in the middle Albian and as the position of this assemblage in the section is below upper Albian beds, it is possible to consider this interval middle Albian.

In Cores 76 to 74, Albian Gaudryina ex gr. spissa (Berthelin), Pleurostomella obtusa Berthelin, as well as peculiar small Osangularia sp. and Baggina sp. appear. This assemblage is also tentatively assigned to the middle Albian.

In overlying beds (Cores 73 to 66), there appear Clavulina gaultina Morozova, Arenobulimina pressli, Reuss varians Tairov, Enantiodentalina communis Marie, Pleurostomella mirabilis Bukalova, along with 
Gyroidinoides spp., Osangularia sp., and Pleurostomella copiosa Bukalova, which are also known from the underlying deposits. All the newly appearing species are common to the late Albian. An assemblage of radiolarians of the Dicyomitra somphedia Zone found there is also upper Albian.

Lenticulina circumcidanea Berthelin, Gavelinella djaffarovi Agalarova, and Pleurostomella subbotinae Djaffarov appear higher in the Lower Cretaceous section (Cores 65 to 59). The most important are Thalmanninella ticinensis (Gandolfi) and Praeglobotruncana delrioensis (Plummer). These indicate the "Vraconian" interval of the late Albian.

From Sample 398D-58-2, 18-20 cm, great changes take place in the content of foraminifers, i.e., representatives of the Upper Cretaceous genera appear, including Hagenowina and Spiroloculina. Pleurostomella and Gyroidinoides change their specific content and representatives of the genus Quadrimorpha appear for the first time. Such planktonic foraminifers as Thalmanninella appeninnica (Reuss) and Heterohelix cenomanica (Agalarova) appear at the same level. These deposits may be assigned to the Cenomanian.

Thus, generally the stratigraphic distribution of benthic foraminifers in Hole 398D show good age-dating agreement with available data on the distribution of planktonic foraminifers and radiolarians, as well as with some age determinations on ammonites.

Benthic foraminifers, owing to their abundance and persistance, allow more detailed subdivisions of the section to be made than do other groups of fauna. They allow substages to be defined, though they do not allow precise placement of the boundaries between them.

Some contradictions as to the position of the Aptian/Albian boundary (caused by the appearance of the benthic Albian species in beds with abundant Hedbergella trochoidea) call for future detailed study of the problem. As we utilized only 10-gram samples, investigators using more material probably can refine and change the position of some of the boundaries.

\section{GEOCHEMISTRY OF DISPERSED ORGANIC MATTER (DOM)}

To study DOM in the Hole 398D interval from 945 to 1740 meters, we prepared six composite samples: Sample $1(59-4$ 98-100 cm; 62-1, 63-65 cm; 62-2, 0-2 cm; $62-5$, 33-35 cm; 63-1, $118-120 \mathrm{~cm}$; 63-3, 7-9 cm; and $63-4,20-22 \mathrm{~cm})$, Sample $2(74-4,81-83 \mathrm{~cm} ; 72-3$, $176-178 \mathrm{~cm} ; 72-7,5-7 \mathrm{~cm} ; 73-1,144-146 \mathrm{~cm} ; 73-4,84-86$ $\mathrm{cm}$; 73-5, 129-131 cm; 74-4, 109-111 cm; and 74-5, 39-41 $\mathrm{cm}$ ), Sample 3 (90-1, $45-47 \mathrm{~cm}$; 91-1, 117-119 cm; 91-2, $113-115 \mathrm{~cm}$; 92-1, 0-2 cm, 130-132 cm; 92-6, 36-38 cm; 95-6, 29-31 cm; 96-5, 32-24 cm; and 97-5, 105-107 cm), Sample 4 (107-4, $92 \mathrm{~cm} ; 108-2,100-102 \mathrm{~cm} ; 108-5,2-4$ $\mathrm{cm}$; $108-7,31-33 \mathrm{~cm} ; 109-4,36-38 \mathrm{~cm} ; 113-2,25-26 \mathrm{~cm}$; $113-4,80-82 \mathrm{~cm}$; and $113-5,41-43 \mathrm{~cm})$, Sample 5 (120-5 $10-12 \mathrm{~cm} ; 120-6,18-20 \mathrm{~cm} ; 121-3,98-100 \mathrm{~cm} ; 121-5$, $45-47 \mathrm{~cm} ; 121-6$, 53-55 cm; 122-2, $42-44 \mathrm{~cm} ; 122-6$, $52-54 \mathrm{~cm}$; and 124-4, 72-72 cm), Sample 6 (133-1, 40-42 cm; $133-3,48-50 \mathrm{~cm}$; $133-5,66-68 \mathrm{~cm} ; 134-1,101-103$ $\mathrm{cm}$; $132-3,56-58 \mathrm{~cm} ; 135-2,43-45 \mathrm{~cm}$; and $138-2$, $133-135 \mathrm{~cm})$.

The studies followed the technique described in our report in Part 1 of this volume.

The interval studied consists mainly of clayey rocks. The carbonate carbon content varies and is at a maximum in Composite Samples 1 and 5 (Table 2).

The luminescent-microscope data (Appendix D) show that the DOM is represented by a dispersed mass which, with the clay, forms a single organic-mineral assemblage with small fragments of fusainized plant tissue, some bright yellow cutin coating, and numerous inciusions of various hydrobiont remains. DOM is of a mixed origin and consists of sapropellic phytotenic and zoogenic matter against a background of clastic transformed and redeposited higher plant matter.

Hydrocarbons of white-blue luminescence occur throughout the section in voids of fossil remains or as films around grains of silt or calcite. Hydrocarbons occur in open horizontal joints at depths of about 1400 and 1500 meters; they are concentrated in pore spaces.

The carbonification level of the organic matter varies from brown coal $\left(B_{3}\right)$ to long flame stage $\left(D_{2}\right)$.

The content of organic carbon range from 0.7 to 1.8 per cent. High values of organic carbon are related to samples with abundant plant remains (Table 2).

The predominance of ferric iron suggests that changes of DOM are mainly due to oxidation conditions. Such conditions are supported by fusainization of organic detritus. Thus, a diagenetic loss of organic carbon during the anaerobic phase for changes of ferric iron into ferrous iron is small and varies from 3 to 6 per cent, with respect to the initial content (Table 3).

A comparative analysis of the content and composition of bitumoids of "open" and "closed" pores (Table 4) shows an absence of true migration processes to a depth of about 1500 meters. Below these depths (Composite Samples 5 and 6), bitumoids of "open" pores become rich in carbon and oils with a slight increase of bitumoid and oil content in DOM (Table 4). We assume that these data, together with the presence of hydrocarbons in pore spaces, reflects the beginning of generation processes and the redistribution of migrationable components. The probability of these processes is confirmed by an increase in methane-naphtene hydrocarbon content in DOM with depth and their redistribution between "closed" and "open" pores in Composite Samples 5 and 6 (Table 4).

Naphthalene, phenatrene, and chrysene structures were found in the hydrocarbons of "open" and "closed" pores. Perylene and possibly phlouranthene are present in Composite Samples 1, 3, 5, and 6. The distribution pattern of aromatic structures confirms the presence of clastic material formed by higher plants in DOM.

infrared spectra of bitumoids in Composite Sample 6 (Figure 7) have strong absorption bands of oxygen compounds of $\mathrm{C}=\mathrm{O}$ groups of fatty acid and ethers $(1700$ and $\left.1740 \mathrm{~cm}^{-1}\right), \mathrm{C}=\mathrm{O}$ bonds of saturated $\left(1170 \mathrm{~cm}^{-1}\right)$ and non-saturated ethers $\left(1290 \mathrm{~cm}^{-1}\right), \mathrm{COOH}$ acid 
TABLE 2

Analyses $^{\mathrm{a}}$ of Dispersed Organic Matter (DOM) From "Open" and "Closed" Pores

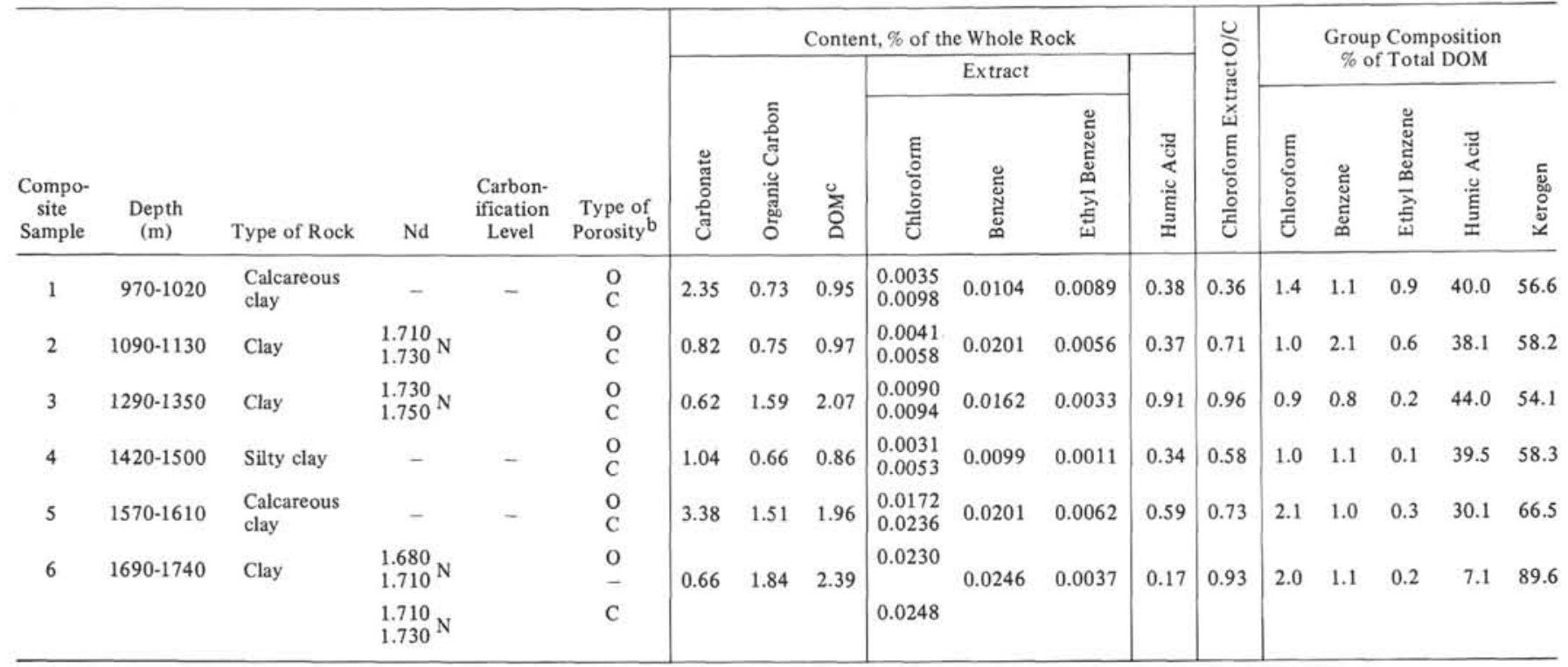

Analysis by Popova I. E., Research Institute of the Geology of the Arctic, Leningrad.

$\mathrm{b}_{\mathrm{O}}=$ open, $\mathrm{C}=$ closed.

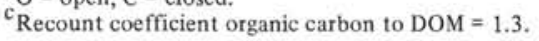

TABLE 3

Level Valuation of Dispersed Organic Matter Diagenetic Anaerobic Transformations

\begin{tabular}{|c|c|c|c|c|c|c|c|c|c|c|c|c|c|c|c|}
\hline \multirow[b]{2}{*}{$\begin{array}{l}\text { Compo- } \\
\text { site } \\
\text { Sample }\end{array}$} & \multirow[b]{2}{*}{$\begin{array}{c}\text { Organic } \\
C(\%)\end{array}$} & \multicolumn{2}{|c|}{$\mathrm{Fe}^{+++}$} & \multicolumn{2}{|c|}{$\mathrm{Fe}^{++}$} & \multirow[b]{2}{*}{ 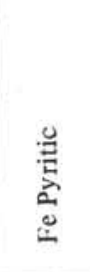 } & \multirow[b]{2}{*}{$\begin{array}{l} \pm \\
\pm \\
\pm \\
\text { 재 } \\
0\end{array}$} & \multirow[b]{2}{*}{ 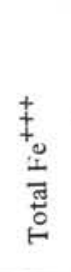 } & \multirow[b]{2}{*}{ 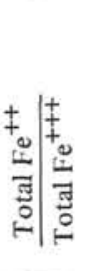 } & \multirow{2}{*}{ 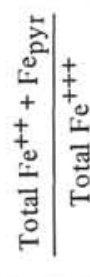 } & \multicolumn{2}{|c|}{ Organic C Discharge } & \multirow[b]{2}{*}{$\begin{array}{c}\text { Total } \\
\text { Organic C } \\
\text { Diagenetic } \\
\text { Anaerobic } \\
\text { Discharge }\end{array}$} & \multirow{2}{*}{ 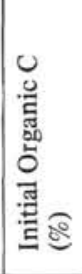 } & \multirow{2}{*}{ 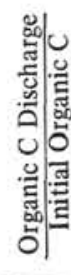 } \\
\hline & & $\begin{array}{c}\text { Easily } \\
\text { Soluble }\end{array}$ & $\begin{array}{l}\text { Diffi- } \\
\text { cultly } \\
\text { Soluble }\end{array}$ & $\begin{array}{c}\text { Easily } \\
\text { Soluble }\end{array}$ & $\begin{array}{c}\text { Diffi- } \\
\text { cultly } \\
\text { Soluble }\end{array}$ & & & & & & for $\mathrm{Fe}^{++}$ & of $\mathrm{Fe}_{\mathrm{pyr}}$ & & & \\
\hline 1 & & & & & 0.14 & 0.011 & 0.39 & 3.08 & 0.13 & 0.13 & 0.021 & 0.0 & 0. & 0.76 & 3.9 \\
\hline 2 & 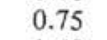 & & & 0. & & & 0 . & 3.45 & 0.09 & 0.09 & & & & 8 & 3.20 \\
\hline 3 & 1.59 & 0.07 & 2.47 & 0.30 & 0.2 & 0.018 & 0.58 & 2.54 & 0.23 & 0.24 & 0.031 & 0 & 0 & 1.64 & 2.74 \\
\hline 4 & 0.66 & 0.06 & 3.03 & 0.21 & 0.07 & 0.017 & 0.28 & 3.09 & 0.09 & 0.096 & 0.015 & 0. & 0. & 0.69 & 4.20 \\
\hline 5 & 1.51 & 0.07 & 3.66 & 0.28 & 0.33 & 0.073 & 0.61 & 3.72 & 0.16 & 0.18 & 0.033 & 0.05 & 0.092 & 1.60 & 5.75 \\
\hline 6 & 1.84 & 0.06 & 2.04 & 0.31 & 0.43 & 0.060 & 0.74 & 2.10 & 0.35 & 0.38 & 0.040 & 0.049 & 0.089 & 1.93 & 4.61 \\
\hline
\end{tabular}

groups $\left(950 \mathrm{~cm}^{-1}\right)$, as well as aromatic $\mathrm{C}=\mathrm{C}$ bonds (1605 and $\left.750 \mathrm{~cm}^{-1}\right)$, and replaced aromatic structures $\left(3070 \mathrm{~cm}^{-1}\right)$. Oxygen structures are more intense in bitumoids of "closed" pores. Absorption bands of phthalates (1120 to 1180,1040 to 1080 , and 1280 to 1300 $\left.\mathrm{cm}^{-1}\right)$, and NH-groups $\left(3200,3400\right.$, and $\left.3500 \mathrm{~cm}^{-1}\right)$ are observed in bitumoid of "open" pores. The presence of phthalate traces suggests oxidizing changes of the bitumoids.

The changes in $n$-alkane distribution at depths of 945 to 1740 meters may be interpreted in different ways (Figure 8, Table 5). Undoubtedly, the peculiar $n$-alkane distribution is largely due to the primary lipid content.

A comparative analysis of $n$-alkane distribution in sediments of the Dead Sea (Nissenbaun et al., 1972) as well as in other regions (Oro et al., 1967; Clark and Blumer, 1965; Winter et al., 1969; Calvin, 1969) showed a predominance of low molecular hydrocarbons $C_{15}-C_{17}$ in deep-water bottom sediments. A comparison with data obtained by Nissenbaum et al., (1972) for deepwater sediments containing clastic plant material shows that the $n$-alkane distribution observed in Composite Samples 1,2 , and 3 is characterized by the absence of $\mathrm{C}_{18-20}$ maximum typical of hydrobiont lipids, and by the presence of long-chained $n$-alkanes typical of terrestrial plants. There is no difference in $n$-alkane distribution between "closed" and "open" pores at a depth of about 1300 meters (Figure 8, Sample 3). A similar pattern of $n$-alkane distribution in Composite Samples 1, 2, and 3 argues for a genetical similarity of DOM in these samples.

Quite a different pattern of $n$-alkane distribution was observed in Composite Samples 5 and 6 at depths of 1570 to 1610 meters and at about 1700 meters (Figure 
TABLE 4

Comparative Analyses a of Bitumoids From "Open" and "Closed" Pores

\begin{tabular}{|c|c|c|c|c|c|c|c|c|c|c|c|c|c|c|c|c|c|c|c|c|c|c|}
\hline \multirow[b]{3}{*}{$\begin{array}{l}\text { Compo- } \\
\text { site } \\
\text { Sample }\end{array}$} & \multirow[b]{3}{*}{$\begin{array}{l}\text { Type of } \\
\text { Porosity } b\end{array}$} & \multicolumn{15}{|c|}{ Composition of Chloroform Bitumoid "A" } & \multicolumn{6}{|c|}{ Composition of Benzene Bitumoid "C" } \\
\hline & & \multicolumn{3}{|c|}{ Elements (\%) } & \multirow[b]{2}{*}{$\frac{\mathrm{C}}{\mathrm{H}}$} & \multirow[b]{2}{*}{$\frac{\mathrm{H}}{\mathrm{C}}$ at. } & \multicolumn{3}{|c|}{$\begin{array}{c}\text { Group } \\
\text { Composition }\end{array}$} & \multicolumn{2}{|c|}{$\begin{array}{c}\text { Hydrocarbons } \\
(\%)\end{array}$} & \multirow[b]{2}{*}{$\frac{\mathrm{Me}-\mathrm{Nf}}{\mathrm{Ar}}$} & \multicolumn{2}{|c|}{$\operatorname{DOM}(\%)$} & \multirow{2}{*}{ 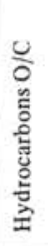 } & \multirow[b]{2}{*}{ 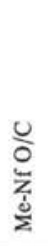 } & \multicolumn{3}{|c|}{$\begin{array}{c}\text { Group } \\
\text { Composition }\end{array}$} & \multicolumn{2}{|c|}{$\begin{array}{c}\text { Hydrocarbons } \\
(\%)\end{array}$} & \multirow[b]{2}{*}{$\frac{\mathrm{Me}-\mathrm{Nf}}{\mathrm{Ar}}$} \\
\hline & & C & $\mathrm{H}$ & $\begin{array}{l}\mathrm{O} \\
+ \\
\mathrm{N} \\
+ \\
\mathrm{S}\end{array}$ & & & 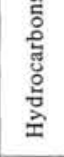 & $\begin{array}{l}\text { है } \\
\ddot{\mathscr{u}}\end{array}$ & 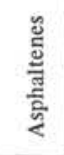 & $\mathrm{Me}-\mathrm{Nf}$ & $\mathrm{Ar}$ & & 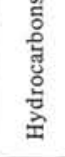 & $\begin{array}{l}\bar{z} \\
\dot{j} \\
z\end{array}$ & & & 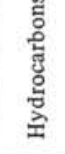 & 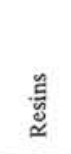 & 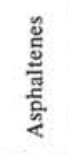 & Me-Nf & Ar & \\
\hline 1 & $\begin{array}{l}\mathrm{O} \\
\mathrm{C}\end{array}$ & $\begin{array}{l}75.0 \\
78.6\end{array}$ & $\begin{array}{l}10.6 \\
11.4\end{array}$ & $\begin{array}{l}14.4 \\
10.0\end{array}$ & $\begin{array}{l}7.1 \\
6.9\end{array}$ & $\begin{array}{l}1.70 \\
1.74\end{array}$ & 26.1 & 12.6 & 59.5 & 48.3 & 51.7 & 0.93 & 0.36 & 0.17 & 0.4 & 0.4 & 14.2 & 11.9 & 71.4 & 58.4 & 41.6 & 1.40 \\
\hline 2 & $\begin{array}{l}\mathrm{O} \\
\mathrm{C}\end{array}$ & $\begin{array}{l}67.8 \\
78.2\end{array}$ & $\begin{array}{r}9.7 \\
11.5\end{array}$ & $\begin{array}{l}22.5 \\
10.3\end{array}$ & $\begin{array}{l}7.0 \\
6.8\end{array}$ & $\begin{array}{l}1.72 \\
1.76\end{array}$ & 14.6 & 24.7 & 56.2 & 84.9 & 15.1 & 5.62 & 0.14 & 0.12 & 0.7 & 0.7 & 29.0 & 12.1 & 57.4 & 90.3 & 9.7 & 9.31 \\
\hline 3 & $\begin{array}{l}\mathrm{O} \\
\mathrm{C}\end{array}$ & $\begin{array}{l}76.7 \\
78.8\end{array}$ & $\begin{array}{l}11.1 \\
11.4\end{array}$ & $\begin{array}{r}12.2 \\
9.8\end{array}$ & $\begin{array}{l}6.9 \\
6.9\end{array}$ & $\begin{array}{l}1.74 \\
1.74\end{array}$ & $\begin{array}{r}9.9 \\
15.8\end{array}$ & $\begin{array}{l}10.4 \\
17.1\end{array}$ & $\begin{array}{l}76.9 \\
65.8\end{array}$ & $\begin{array}{l}44.4 \\
83.5\end{array}$ & $\begin{array}{l}55.6 \\
16.5\end{array}$ & $\begin{array}{l}0.80 \\
5.06\end{array}$ & $\begin{array}{l}0.04 \\
0.08\end{array}$ & $\begin{array}{l}0.02 \\
0.07\end{array}$ & 0.5 & 0.3 & 11.5 & 20.8 & 67.7 & 53.0 & 47.0 & 1.13 \\
\hline 4 & $\begin{array}{l}\mathrm{O} \\
\mathrm{C}\end{array}$ & $\begin{array}{l}67.3 \\
79.1\end{array}$ & $\begin{array}{r}9.4 \\
11.3\end{array}$ & $\begin{array}{r}23.3 \\
9.6\end{array}$ & $\begin{array}{l}7.2 \\
7.0\end{array}$ & $\begin{array}{l}1.68 \\
1.71\end{array}$ & & & & & No d: & & & & & & 15.1 & 33.3 & 51.2 & 61.7 & 38.3 & 1.61 \\
\hline 5 & $\begin{array}{l}\mathrm{O} \\
\mathrm{C}\end{array}$ & $\begin{array}{l}79.1 \\
75.6\end{array}$ & $\begin{array}{l}11.8 \\
10.5\end{array}$ & $\begin{array}{r}9.1 \\
13.9\end{array}$ & $\begin{array}{l}6.7 \\
7.2\end{array}$ & $\begin{array}{l}1.79 \\
1.67\end{array}$ & $\begin{array}{l}12.6 \\
15.4\end{array}$ & $\begin{array}{l}24.5 \\
12.7\end{array}$ & $\begin{array}{l}62.9 \\
68.6\end{array}$ & $\begin{array}{l}52.4 \\
50.0\end{array}$ & $\begin{array}{l}47.6 \\
50.0\end{array}$ & $\begin{array}{l}1.10 \\
1.00\end{array}$ & $\begin{array}{l}0.11 \\
0.18\end{array}$ & $\begin{array}{l}0.06 \\
0.09\end{array}$ & 0.6 & 0.7 & 7.8 & 7.1 & 81.6 & 55.1 & 44.9 & 1.23 \\
\hline 6 & $\begin{array}{l}\mathrm{O} \\
\mathrm{C}\end{array}$ & $\begin{array}{l}80.5 \\
78.3\end{array}$ & $\begin{array}{l}10.8 \\
10.8\end{array}$ & $\begin{array}{r}8.7 \\
10.9\end{array}$ & $\begin{array}{l}7.4 \\
7.3\end{array}$ & $\begin{array}{l}1.61 \\
1.66\end{array}$ & $\begin{array}{l}18.7 \\
15.7\end{array}$ & $\begin{array}{l}9.6 \\
8.2\end{array}$ & $\begin{array}{l}67.4 \\
76.0\end{array}$ & $\begin{array}{l}34.8 \\
47.8\end{array}$ & $\begin{array}{l}65.2 \\
52.2\end{array}$ & $\begin{array}{l}0.53 \\
0.91\end{array}$ & $\begin{array}{l}0.19 \\
0.16\end{array}$ & $\begin{array}{l}0.07 \\
0.08\end{array}$ & 1.2 & 0.9 & 4.0 & 5.5 & 88.2 & 40.0 & 60.0 & 0.67 \\
\hline
\end{tabular}

${ }^{a}$ Analysis by I. S. Kozlova, Research Institute of the Geology of the Arctic, Leningrad.

${ }^{\mathrm{b}} \mathrm{O}=$ open, $\mathrm{C}=$ closed.

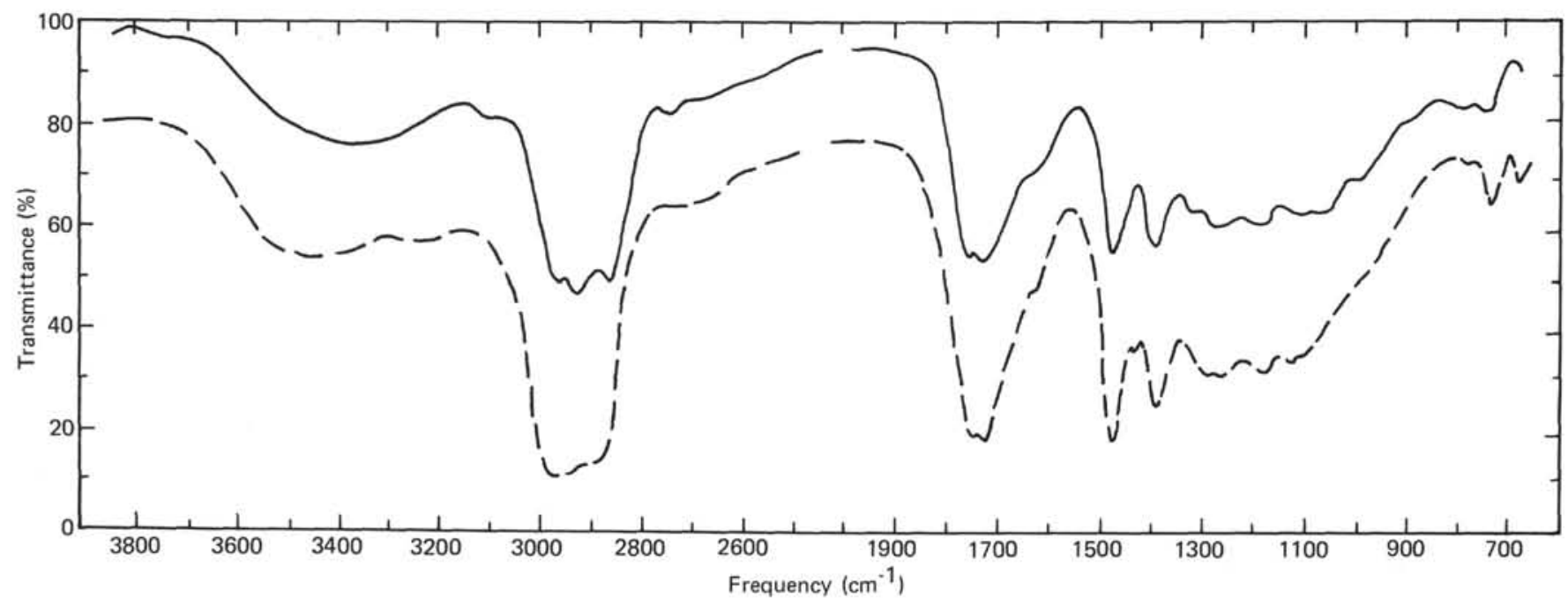

Figure 7. Comparison of I-R spectra of bitumoides from "open" pores (represented by dashed line) and "closed" pores (solid line).

8). From Composite Samples 3 to 6 , there is a marked increase with depth of short-chained $n$-alkanes $\left(C_{14}\right.$ to $\mathrm{C}_{22}$ ) in "closed" pores and a decrease in long-chained $n$-alkanes until the $\mathrm{C}_{29-35}$ fraction disappears in Sample 6. In our opinion, the "closed" pores may be replenished by short-chained hydrocarbons owing to destruction of DOM and breakage of long chains in a zone of primary catagenesis at a depth more than 1500 meters. Long-flame stage of carbonification of DOM corresponds to this depth level. An observed decrease of CPI in "open" and "closed" pores also implies a higher level of DOM changes at depths of 1600 to 1700 meters (Table 5).
In conclusion, DOM in Hole 398D is of mixed genesis and was formed by autochthonous sapropellic phytogenic and zoogenic material as well as by allochthonous fragments of higher plants. DOM has features of changes under oxidizing conditions and consists mainly of humic acids. The formation of DOM probably followed the melanoidine trend (Manskaya and Drozdova, 1966). More detailed conclusions on changes of organic matter will result from the study of humic acids, amino acid composition, and insoluble components (kerogen).

The available data support the observation that, to a depth of 1500 meters, a composition of DOM is 

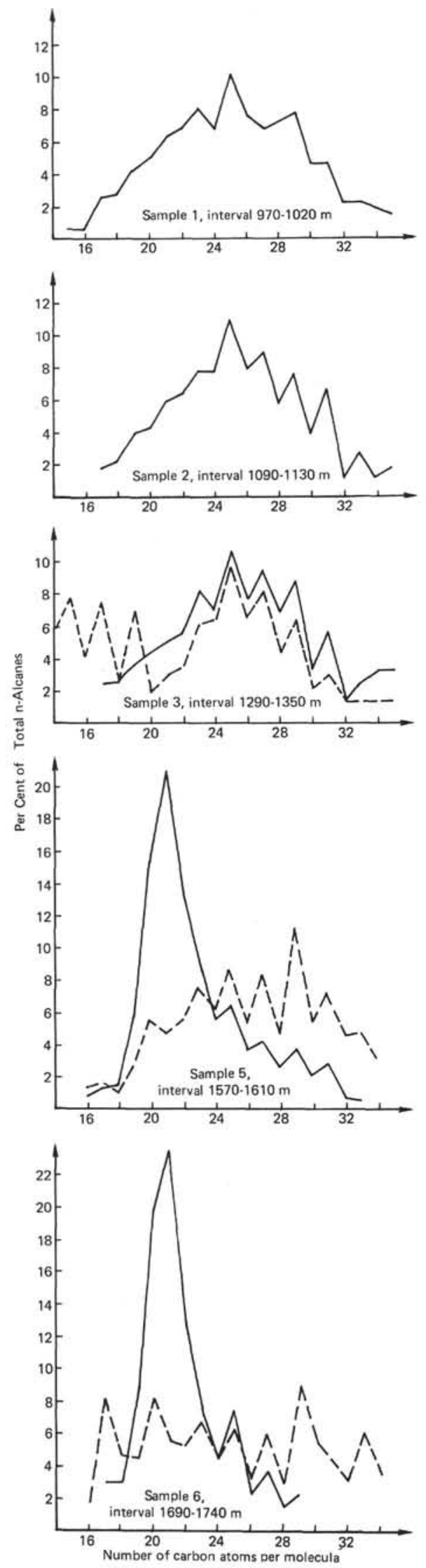

Figure 8. Distribution of n-alkanes from "open" pores (represented by dashed lines) and "closed" pores (solid lines). regulated mainly by facial-genetic factors; at greater depths, the changes of DOM are owing to destructions in a zone of primary catagenesis. Hence, 1500 meters may be considered an upper limit of hydrocarbon generation. Below this limit, at a depth of about 1700 meters, there begins a migrational redistribution of hydrocarbons.

\section{CONCLUSION}

Analysis of microfossil distribution in the stratigraphic section is of great importance for reconstructing sedimentary environments. Using foraminiferal assemblages related to different environments, we recognized three stages in the development of an Early Cretaceous sedimentary basin.

1) Hauterivian-early Aptian stage (Cores 138 to 120 ): Marked by the predominance of benthic calcareous foraminifers of the families Nodosariidae and Epistominidae. The assemblage contains many large sculptured forms (Lenticulina ouachensis Sigal, Hoeglundina ex gr. spinulifera [Reuss], and others). Some layers yield abundant radiolarians. Similar microfossil associations are common for western European epicontinental marine basins, where they seem to have inhabited warm waters of the external sublittoral.

The same assemblage of foraminifers is characteristic of units of different lithology, i.e., mainly pelitomorphic limestone (Unit 1) from Cores 138 to 130, terrigenous deposits of slope slumps and turbidites (Unit 2) from Cores 130 to 120 . If the accumulation of calcareous sediments took place on the upper slope, then clastic turbiditic-slumping sedimentation marks the initial deepening of the basin under conditions of a steeper continental slope and/or prodeltaic environment.

2) Middle Aptian-early Albian stage (Cores 118 to 87): This interval differs by periodic changes of the environment. One type of environment is marked by mainly "primitive" agglutinated foraminifers (Cores $118-117,114-113,112-111,108-107,104-103$, and other) and by the domination among them of small, thinwalled baculiform tests of the families Astrorhizidae, Saccaminidae, Ammodiscidae, and Lituolidae. Radiolarians are also abundant. The second type of environment is marked by mixed assemblages (Sections 111-1, 98-1, 95-5, 93-3, and others). Here, in addition to "primitive" agglutinated foraminifers, we found highly organized families such as Textularidae and Ataxophragmiidae and scarce calcareous foraminifers of Osangulariidae, Anomalinidae, Nodosariidae, and others. In a third type of environment, the assemblages of calcareous foraminifers (Section 116-1, Cores 115 and 104 to 108, Section 99-3, and others) are represented mainly by the above-mentioned families but with an almost complete absence of agglutinated forms. The absence of calcareous tests (especially planktonic) is usually accounted for by the solution of calcium carbonate below the CCD. However, we did not observe distinct dissolution of calcareous tests within strata of the second and third environmental types, where 
TABLE 5

Distribution of $n$-Alkanes ${ }^{\mathrm{a}}$

\begin{tabular}{|c|c|c|c|c|c|c|c|c|c|c|c|}
\hline \multirow{2}{*}{$\begin{array}{c}\text { Compo- } \\
\text { site. } \\
\text { Sample }\end{array}$} & \multirow[b]{2}{*}{$\begin{array}{l}\text { Type of } \\
\text { Porosity }\end{array}$} & \multicolumn{2}{|c|}{ DOM $(\%)$} & \multirow[b]{2}{*}{$\begin{array}{l}\text { Me-Nf \% of } \\
\text { Hydrocarbons }\end{array}$} & \multicolumn{6}{|c|}{ Distribution of $n$-Alkanes (\% of total) } & \multirow[b]{2}{*}{ CPI } \\
\hline & & 気 & 孞 & & $\mathrm{C}_{14-17}$ & $\mathrm{C}_{18-24}$ & $\mathrm{C}_{25-28}$ & $\mathrm{C}_{29-35}$ & $\mathrm{C}_{14-22}$ & $\mathrm{C}_{23-35}$ & \\
\hline 1 & $\begin{array}{l}\mathrm{O} \\
\mathrm{C}\end{array}$ & 0.36 & 0.17 & 48.3 & 3.7 & 39.8 & 31.8 & 24.7 & 28.7 & 71.3 & 1.32 \\
\hline 2 & $\begin{array}{l}\mathrm{O} \\
\mathrm{C}\end{array}$ & 0.14 & 0.12 & 84.9 & 1.8 & 38.7 & 33.9 & 25.6 & 24.9 & 75.1 & 1.29 \\
\hline 3 & $\begin{array}{l}\mathrm{O} \\
\mathrm{C}\end{array}$ & $\begin{array}{l}0.04 \\
0.08\end{array}$ & $\begin{array}{l}0.02 \\
0.07\end{array}$ & $\begin{array}{l}44.4 \\
83.5\end{array}$ & $\begin{array}{r}25.0 \\
2.5\end{array}$ & $\begin{array}{l}30.4 \\
36.0\end{array}$ & $\begin{array}{l}28.5 \\
34.2\end{array}$ & $\begin{array}{l}16.1 \\
27.3\end{array}$ & $\begin{array}{l}42.9 \\
23.6\end{array}$ & $\begin{array}{l}57.1 \\
76.4\end{array}$ & $\begin{array}{l}1.47 \\
1.38\end{array}$ \\
\hline 5 & $\begin{array}{l}\mathrm{O} \\
\mathrm{C}\end{array}$ & $\begin{array}{l}0.11 \\
0.18\end{array}$ & $\begin{array}{l}0.06 \\
0.09\end{array}$ & $\begin{array}{l}52.4 \\
50.0\end{array}$ & $\begin{array}{l}2.9 \\
2.1\end{array}$ & $\begin{array}{l}33.6 \\
70.9\end{array}$ & $\begin{array}{l}27.2 \\
17.1\end{array}$ & $\begin{array}{r}36.3 \\
9.9\end{array}$ & $\begin{array}{l}22.7 \\
58.7\end{array}$ & $\begin{array}{l}77.3 \\
41.3\end{array}$ & $\begin{array}{l}1.42 \\
1.34\end{array}$ \\
\hline 6 & $\begin{array}{l}\mathrm{O} \\
\mathrm{C}\end{array}$ & $\begin{array}{l}0.19 \\
0.16\end{array}$ & $\begin{array}{l}0.07 \\
0.08\end{array}$ & $\begin{array}{l}34.8 \\
47.8\end{array}$ & $\begin{array}{l}9.7 \\
6.0\end{array}$ & $\begin{array}{l}39.8 \\
84.1\end{array}$ & $\begin{array}{r}18.7 \\
9.9\end{array}$ & $\begin{array}{l}31.8 \\
-\end{array}$ & $\begin{array}{l}38.0 \\
78.0\end{array}$ & $\begin{array}{l}62.0 \\
22.0\end{array}$ & $\begin{array}{l}1.38 \\
0.75\end{array}$ \\
\hline
\end{tabular}

${ }_{b}^{a}$ Analysis by Yu. S. Schelovanov, VNIGRI, Leningrad.

$\mathrm{b}_{\mathrm{O}}=$ open, $\mathrm{C}=$ closed.

planktonic foraminifers appear and remains of calcareous nannofossils are common. Therefore, we suggest that beds with agglutinated foraminifers formed under conditions of restricted circulation and stagnant water. Clayey strata there have geochemical features implying slightly freshened waters. These features are a lower magnesium content of the alkaline earth cations, and a relatively low potassium content. Abundant beds of manganese-ferrous carbonates associated with the assemblages of agglutinated foraminifers support the interpretation of a reducing environment.

The assemblages of the second and the third environmental types contain no sculptured nodosariids and a number of genera characteristic of Early Cretaceous epicontinental basins. Planktonic foraminifers are very abundant in some layers. The agglutinated foraminifers of the first two assemblages are dominated by cosmopolitan forms common to both Tethys and near polar regions (in Alaska). There, forms related to Recent moderately deep-water ocean basins occur among calcareous foraminifers. This implies greater depths and lower bottom-water temperature in the early-middle Albian basin. Amounts of manganeseferrous carbonate decrease and the magnesium content of alkaline earth cations increases in the layers where calcareous foraminifers are common. This indicates the environment of a normal marine basin with prevailing oxidizing conditions.

Apparently, sedimentation during Stage 2 took place under conditions of a deepening and periodically stagnant basin within the lower part of the continental slope; a basin effected by sediment transport from the continent. The presence of organic detritus mainly of plant origin, the carbonate enrichment in manganese, as well as a high kaolinite clay content implies a nearby source area.
3) Middle-late Albian stage (Cores 85 to 59). This stage is characterized by the predominance of calcareous foraminifers of the families Odangulariidae, Anomalinidae, Pleurostomellidae, Eponididae, and Buliminidae. The diversity of planktonic foraminifers is large. Layers with primitive agglutinated foraminifers become scarce; Ataxophragmiidae predominate. The microfossil assemblage is similar to coeval foraminifers of the Greater Caucasus (Djafarov et al., 1951). According to G.E. Kozlova, this is also true of the radiolarians. Comparison of benthic and Recent foraminifers shows that their generic composition is most similar to the buliminide-rotaliid taxocoenosis (Saidova, 1976) typical of bathyal areas (750 to $2750 \mathrm{~m}$ ). Apparently, it was a time of further widening of the North Atlantic basin with a connection to the Tethys still existing.

During the Early Cretaceous, a gradual change of three major environments took place in the Galicia Bank area, namely: (1) open external sublittoral with predominantly carbonate sedimentation (HauterivianBarremian), (2) differing slope settings when stagnant conditions periodically existed (Aptian-lower Albian), and (3) an open oceanic slope setting (middle-late Albian) when the importance of pelagic sedimentation increased.

The data obtained do not allow us to date rifting and the beginning of sea-floor spreading.

A peculiar feature of the Lower Cretaceous section is a high contamination by dispersed organic matter, along with the wide distribution of manganese-ferrous carbonates. DOM is of mixed genesis and is composed of allochthonous remains of higher plants and autochthonous sapropel phytogenic and zoogenic material. Within the interval down to 1500 meters, the composition of DOM is determined by facies-genetic 
factors and, at deeper layers, is marked by destructive changes corresponding to initial catagensis. The upper limit of hydrocarbon generation is at a depth of about 1500 meters. At a depth of about 1700 meters, migrational redistribution of hydrocarbons has begun.

Siderite and manganese siderite were formed by diagensis of calcareous-clay sediments under highly reducing conditions and high partial $\mathrm{CO}_{2}$ pressure. The decomposition of DOM which directly correlates with the distribution of carbonate throughout the section suggests reducing conditions. Iron and manganese necessary for the formation of the carbonates seem to have been supplied in the adsorbed state on clay particles.

\section{ACKNOWLEDGMENTS}

The authors are indebted to Dr. T.N. Gorbachik (The University of Moscow) for determination of planktonic foraminifers, to Dr. G.E. Kozlova (Research Petroleum Institute, Leningrad) for determination of radiolarians, and to Dr. T.E. Baranova (Research Petroleum Institute, Leningrad) for the summary of luminescent-microscopic analysis. Thanks are extended to Dr. N.N. Lapina (Research Institute of the Geology of the Arctic, Leningrad) who kindly reviewed the manuscript and provided expert advice. We are grateful to Dr. N.V. Sharovskaya for identifying and drawing some agglutinated foraminifers.

\section{REFERENCES}

Aliev, K.S., 1965. Radiolarians of Lower Cretaceous sediments in the northern-eastern Azerbaijan and their stratigraphic significance (in Russian), Academy of Science of Azerbaijan Soviet Socialist Republic, Baku, p. 124.

Antonova, Z.A., Shmygina, T.A., Gendina, A.G., and Kalugina, O.M., 1964. Neocomian and Aptian foraminifers of the Pshekhaubin region (the northern-western Caucasus) (in Russian), Trudy Krasnodarskogo filiala VNIINEFTGAS, v. 12, p. 2-72.

Bencini, A. and Turi, A., 1974. Mn distribution in the Mesozoic carbonate rocks from Lima Valley, northern Appennines, J. Sediment. Petrol., v. 44, p. 774-782.

Brockamp, O., 1976. Dissolution and transport of manganese by organic acids and their role in sedimentary $\mathrm{Mn}$ ore formation, Sedimentology, v. 23, p. 579-586.

Calvin, M., 1969. The nature of hydrocarbons in microorganisms, Chemical evolution: Oxford (Cambridge University Press), p. 39-69.

Clark, E. and Blumer, M., 1965. Distribution of $n$-paraffins marine organisms and sediments, Limnol. Oceanogr., v. 12 , p. $79-87$.

Djafarov, D.J., Agalarova, D.A., and Khalilov, D.M., 1951. Reference book on the Lower Cretaceous microfauna of Azerbaijan sedimentary rocks (in Russian), Gostoptekhizdat, Baku, p. 128.

Foreman, H.P., 1975. Radiolaria from the North Pacific, Leg 32. In Larson R.L., Moberly R., et al., Initial Reports of the Deep Sea Drilling Project, v. 32: Washington (U.S. Government Printing Office), p. 579-676.

Manskaya, S.M. and Drozdova, T.V., 1964. Geochemistry of organic matter (in Russian): Moskva (Isdatelstvo "Nauka"), p. 69-87.

Moullade, M., 1966. Etude stratigraphique et micropaléontologique du crétacé inferieur de la "fosse vocontienne," Doc. Lab. Géol. Fac. Sci. Lyon, no. 15, p. 369.
Nissenbaum, A., Baedecker, M., and Kaplan, I., 1972. Organic geochemistry of Dead Sea sediments, Geochim. Cosmochim. Acta, v. 36, p. 709-727.

Oro, J., Tornabene, T., Nooner, P., and Celpi, E., 1967. Aliphatic hydrocarbons and fatty acids of some marine and fresh water microorganism, J. Bacteriol., v. 93, p. 18111818.

Riedel, W.R. and Sanfilippo, A., 1974. Radiolaria from the southern Indian Ocean, In Davies, T.A., Luyendyk, B.P., et al., Initial Reports of the Deep Sea Drilling Project, v. 26: Washington (U.S. Government Printing Office), p. 771-814.

Saidova, K.M., 1976. Benthic foraminifers of the World Ocean (in Russian): Moskva (Izdatelstvo "Nauka"), p. 160 .

Stashchuk, M.F., 1973. Authigenic minerals as indicators of physical and chemical conditions of sedimentary rocks origin (in Russian), First International Geochemical Congress, v. 2 Processes of sedimentation, Moskva, p. 38-45.

Timofeeva, Z.V., 1963. Siderite in shallow water and deltaic sediments and factors responsible for its origin (in Russian). Sbornik "Del'tovye i melkovodno-morskie otlozeniya": Moskva (Izdatelstvo "Nauka”), p. 174-179.

Tsirekidze, L.R., 1971. On Albian stratigraphy of southern and eastern edges of Dzirul Massif by foraminifer fauna (in Russian), Soobshchenie Akademii Nauk Gruzinskoi $S S P$, v. 61, p. 113-116.

Winter, K., Parker, P., and Van Baalen, C., 1969. Hydrocarbons of blue-green algae: geochemical significance, Science, v. 1963 , p. $467-468$.

\section{APPENDIX A}

Composition of Hole 398D Clay Minerals, Weight Per Cent (X-ray analysis on diffractometer DRON-1)

\begin{tabular}{|c|c|c|c|c|}
\hline $\begin{array}{c}\text { Sample } \\
(\text { Interval in } \mathrm{cm})\end{array}$ & Illite & Chlorite & Montmorillonite & Kaolinite \\
\hline $56-2,22-24$ & 20 & 5 & 65 & 10 \\
\hline $56-2,95-97$ & 10 & - & 85 & 5 \\
\hline $56-4,110-112$ & 15 & 5 & 75 & 5 \\
\hline $57-1,62-64$ & 10 & 5 & 80 & 5 \\
\hline $57-1,113-115$ & 15 & 5 & 75 & 5 \\
\hline $59-2,84-86$ & 10 & 5 & 85 & - \\
\hline $62-3,34-36$ & 25 & 5 & 70 & - \\
\hline $62-6 ; 14-16$ & 30 & 5 & 60 & 5 \\
\hline $63-1,30-32$ & 25 & 5 & 65 & 5 \\
\hline $63-5,120-122$ & 30 & 5 & 60 & 5 \\
\hline $65-6,38-40$ & 30 & 5 & 60 & 5 \\
\hline $67-2,69-71$ & 35 & 5 & 60 & - \\
\hline $68-5,80-86$ & 25 & 5 & 65 & 5 \\
\hline $70-2,77-79$ & 20 & - & 70 & 10 \\
\hline $71-1,49-51$ & 25 & - & 75 & - \\
\hline $71-2,106-108$ & 30 & 5 & 60 & 5 \\
\hline $72-3,65-67$ & 25 & - & 75 & - \\
\hline $73-3,40-42$ & 15 & - & 75 & 10 \\
\hline $74-3,57-59$ & 40 & 5 & 40 & 15 \\
\hline $75-4,7-9$ & 50 & 5 & 40 & 5 \\
\hline $76-2,28-30$ & 35 & 5 & 60 & - \\
\hline $77-4,48-51$ & 45 & 5 & 40 & 10 \\
\hline $77-5,45-47$ & 40 & 5 & 55 & - \\
\hline $79-3,105-107$ & 40 & 5 & 55 & - \\
\hline $82-1,48-50$ & 30 & 5 & 60 & 5 \\
\hline $82-2,99-101$ & 30 & 5 & 55 & 10 \\
\hline $82-4,100-102$ & 35 & 5 & 55 & 5 \\
\hline $84-3,12-14$ & 40 & 5 & 45 & 10 \\
\hline $84-5,22-24$ & 15 & 5 & 70 & 10 \\
\hline $85-2,128-130$ & 20 & 5 & 70 & 5 \\
\hline
\end{tabular}


APPENDIX A - Continued

\begin{tabular}{lcccc}
\hline $\begin{array}{c}\text { Sample } \\
\text { (Interval in cm) }\end{array}$ & Illite & Chlorite & Montmorillonite & Kaolinite \\
\hline $85-4,94-96$ & 30 & 5 & 55 & 10 \\
$86-5,102-104$ & 35 & 5 & 50 & 10 \\
$87-2,5-6$ & 20 & 5 & 60 & 15 \\
$88-2,98-100$ & 20 & 5 & 60 & 15 \\
$89-1,35-37$ & 20 & 5 & 55 & 20 \\
$91-5,19-20$ & 20 & 5 & 65 & 10 \\
$92-2,57-59$ & 25 & 5 & 60 & 10 \\
$93-2,76-78$ & 15 & 5 & 65 & 15 \\
$93-2,148-151$ & 20 & 5 & 60 & 15 \\
$93-6,80-86$ & 20 & 5 & 60 & 15 \\
$95-4,112-114$ & 15 & 5 & 65 & 15 \\
$96-4,36-44$ & 15 & 5 & 65 & 15 \\
$97-4,100-103$ & 20 & 5 & 60 & 15 \\
$99-1,26-28$ & 20 & 5 & 60 & 15 \\
$99-2,34-43$ & 15 & - & 70 & 15 \\
$100-1,132-136$ & 20 & - & 65 & 15 \\
$100-3,123-125$ & 20 & - & 70 & 10 \\
$101-4,68-70$ & 10 & - & 80 & 10 \\
$103-1,132-134$ & 10 & 5 & 75 & 10 \\
$104-1,48-58$ & 20 & 5 & 70 & 5 \\
$104-3,143-145$ & 10 & - & 85 & 5 \\
$105-1,148-150$ & 15 & 5 & 75 & 5 \\
$106-2,73-75$ & 10 & 5 & 75 & 10 \\
$107-3,22-24$ & 15 & 5 & 75 & 5 \\
$108-4,127-129$ & 25 & 5 & 55 & 15 \\
$109-1,45-47$ & 15 & 5 & 70 & \\
$111-2,76-78$ & 10 & 5 & 80 & \\
\hline & & & & 5 \\
\hline
\end{tabular}

APPENDIX A - Continued

\begin{tabular}{lcccc}
\hline $\begin{array}{c}\text { Sample } \\
\text { (Interval in cm) }\end{array}$ & Illite & Chlorite & Montmorillonite & Kaolinite \\
\hline $113-2,25-26$ & 15 & - & 75 & 10 \\
$115-1,1-5$ & 15 & 5 & 75 & 5 \\
$115-3,71-73$ & 15 & - & 75 & 10 \\
$117-2,78-96$ & 25 & 5 & 65 & 5 \\
$117-6,82-87$ & 20 & 5 & 70 & 5 \\
$119-1,68-70$ & 25 & - & 70 & 5 \\
$120-2,77-79$ & 20 & 5 & 70 & 5 \\
$121-4,28-30$ & 10 & - & 85 & 5 \\
$123-3,56-64$ & 25 & 5 & 60 & 10 \\
$123-4,0-11$ & 25 & 5 & 70 & - \\
$125-3,30-32$ & 15 & - & 80 & 5 \\
$126-6,70-78$ & 20 & 5 & 65 & 10 \\
$127-3,89-98$ & 40 & 5 & 55 & - \\
$128-1,49-51$ & 25 & 10 & 60 & 5 \\
$130-1,0-10$ & 25 & 5 & 65 & 5 \\
$130-4,30-38$ & 25 & 5 & 65 & 5 \\
$132-1,73-80$ & 25 & 5 & 60 & 10 \\
$132-2,18-21$ & 15 & - & 75 & 10 \\
$133-1,123-127$ & 35 & 5 & 55 & 5 \\
$133-5,30-40$ & 10 & - & 85 & 5 \\
$136-1,44-53$ & 10 & 5 & 75 & 10 \\
$136-3,29-33$ & 15 & 5 & 75 & 5 \\
$136-3,125-134$ & 15 & 5 & 75 & 5 \\
$137-1,94-100$ & 15 & 5 & 75 & 5 \\
$137-3,36-47$ & 10 & - & 85 & 5 \\
$137-3,146-150$ & 20 & 5 & 70 & 5 \\
$137-5,12-18$ & 10 & 5 & 80 & \\
\hline & & & & 5 \\
\hline
\end{tabular}


APPENDIX B

Composition of Absorbed Cations From Hole 398D Samples

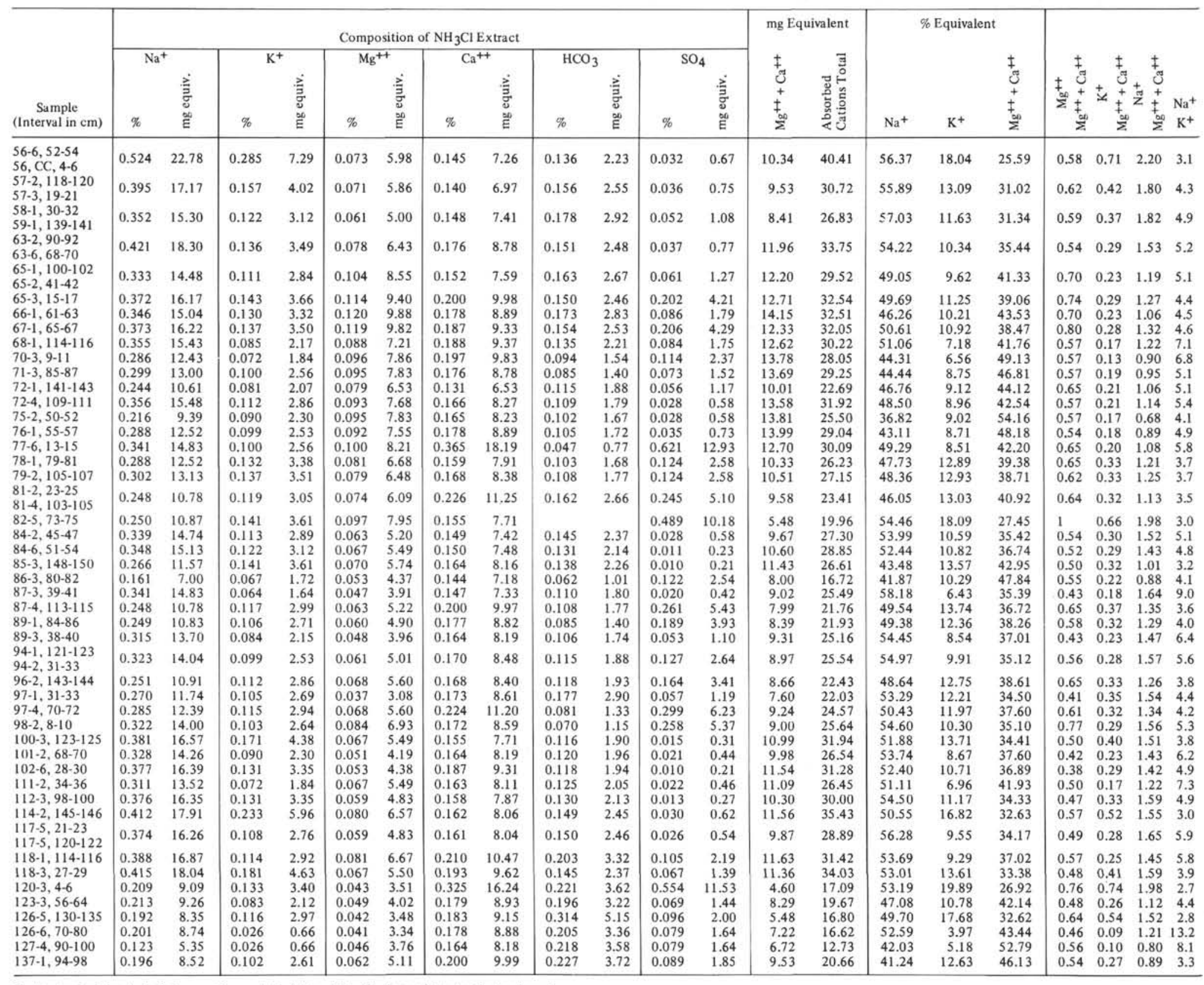

Note: Analysis by A. F. Zelenova, Research Institute of the Geology of the Arctic, Leningrad. 
APPENDIX C

Composition of Difficultly Soluble Components From Hole 398D Samples

\begin{tabular}{|c|c|c|c|c|c|c|c|c|c|c|c|c|c|c|c|c|c|c|c|c|c|c|}
\hline $\begin{array}{c}\text { Sample } \\
\text { (Interval in cm) }\end{array}$ & 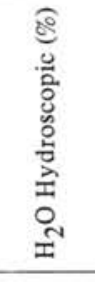 & 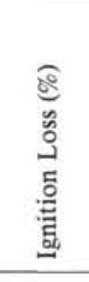 & 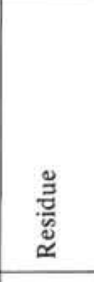 & ळั & ঠ్స & ֶֻ & 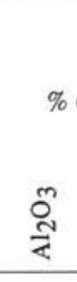 & of Dry Ro & ల్ల & $\sum_{\substack{\mathrm{B} \\
2}}$ & §̊ & $\delta$ & 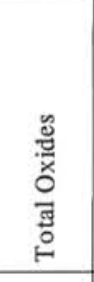 & 尺ิ & ర్ల & ్ֻఝ & ঠ্ন & 怘 & O & $\sum_{\Sigma}^{\circ}$ & @ & 尺 \\
\hline 1 & 2 & 3 & 4 & 5 & 6 & 7 & 8 & 9 & 10 & 11 & 12 & 13 & 14 & 15 & 16 & 17 & 18 & 19 & 20 & 21 & 22 & 23 \\
\hline $\begin{array}{l}56-\mathrm{CC}, 4-6 \\
56-6,52-54\end{array}$ & 5.77 & 22.01 & 59.00 & 1.83 & 0.23 & 0.09 & 1.74 & 0.256 & 18.20 & 0.66 & 0.04 & 17.65 & 40.70 & 30.45 & 1.44 & 0.63 & 17.07 & 3.61 & 324.54 & 16.37 & 0.50 & 401.04 \\
\hline $58-1,30-32$ & 7.68 & 17.68 & 63.77 & 0.99 & 0.35 & & 2.07 & 0.305 & 12.57 & 1.09 & 0.10 & 12.89 & 30.37 & 16.48 & 2.19 & & 20.30 & 4.30 & 224.15 & 27.03 & 1.25 & 292.89 \\
\hline $\begin{array}{l}65-1,100-102 \\
65-2,41-42\end{array}$ & 9.96 & 14.55 & 76.87 & 4.68 & 0.22 & 0.13 & 1.81 & 0.533 & 7.75 & 0.44 & 0.22 & 6.35 & 22.13 & 77.88 & 1.38 & 0.92 & 17.75 & 7.51 & 138.20 & 10.91 & 2.75 & 144.28 \\
\hline $66-1,61-63$ & 13.40 & 9.54 & 89.00 & 1.10 & 0.21 & & 1.96 & 0.462 & 2.42 & 0.65 & 0.22 & 2.61 & 9.63 & 18.31 & 1.32 & & 19.22 & 6.51 & 43.15 & 16.12 & 2.75 & 59.30 \\
\hline $68-1,114-116$ & 11.81 & 8.32 & 92.26 & 0.66 & 0.26 & 0.10 & 1.30 & 0.097 & 1.99 & 0.30 & 0.24 & 1.89 & 6.84 & 10.98 & 1.63 & 0.71 & 12.75 & 1.37 & 35.49 & 7.44 & 3.00 & 42.93 \\
\hline $72-1,141-143$ & 7.83 & 15.91 & 65.52 & 2.12 & 1.68 & 0.23 & 2.12 & 12.78 & 2.91 & 0.36 & 0.13 & 11.91 & 34.24 & 35.28 & 10.52 & 1.62 & 20.79 & 180.1 & 51.89 & 8.93 & 1.62 & 270.62 \\
\hline $72-4,109-111$ & 10.50 & 7.24 & 93.58 & 0.80 & 0.15 & 0.08 & 0.90 & 0.056 & 1.09 & 0.49 & 0.08 & 1.63 & 5.28 & 13.31 & 0.94 & 0.56 & 8.83 & 0.79 & 19.44 & 12.15 & 1.00 & 37.04 \\
\hline $75-2,50-52$ & 10.10 & 8.54 & 92.87 & 0.63 & 0.24 & 0.22 & 1.28 & 0.064 & 1.86 & 0.30 & 0.16 & 1.63 & 6.38 & 10.48 & 1.50 & 1.55 & 12.55 & 0.90 & 33.17 & 7.44 & 2.00 & 37.04 \\
\hline $77-6,13-15$ & 12.08 & 7.31 & 93.28 & 0.78 & 0.73 & 0.12 & 0.64 & 0.036 & 0.71 & 0.30 & 1.15 & 1.23 & 5.70 & 12.98 & 4.57 & 0.85 & 6.28 & 0.51 & 12.66 & 7.44 & 14.36 & 27.95 \\
\hline $79-2,105-107$ & 13.93 & 7.35 & 94.74 & 1.05 & 0.27 & 0.06 & 0.82 & 0.044 & 0.56 & 0.40 & 0.28 & 0.88 & 4.36 & 17.47 & 1.69 & 0.42 & 8.04 & 0.62 & 9.99 & 9.92 & 3.50 & 19.91 \\
\hline $\begin{array}{l}81-2,23-25 \\
81-4,103-105\end{array}$ & 4 & 12.97 & .00 & 1.31 & 0.98 & 0.22 & 4.03 & 3.170 & 5.58 & 0.58 & 0.45 & 8.48 & 24.80 & 1.80 & 6.14 & 1.55 & 39.53 & 4.69 & 9.50 & 14.39 & 5.62 & 192.68 \\
\hline $82-5,73-75$ & 10.53 & 11.36 & 94.79 & 0.66 & 1.10 & 0.20 & 0.43 & 0.041 & 0.30 & 0.11 & 1.17 & 0.80 & 4.81 & 10.98 & 6.89 & 1.41 & 4.22 & 0.58 & 5.35 & 2.73 & 14.61 & 18.18 \\
\hline $84-6,51-54$ & 14.04 & 5.78 & 95.77 & 0.83 & 0.17 & 0.06 & 1.30 & 0.024 & 0.41 & 0.22 & 0.06 & 0.56 & 3.63 & 13.81 & 1.06 & 0.42 & 12.75 & 0.34 & 7.31 & 5.46 & 0.75 & 12.72 \\
\hline $85-3,148-150$ & 11.40 & 8.34 & 90.48 & 0.93 & 0.42 & 0.06 & 1.01 & 0.125 & 2.97 & 0.29 & 0.07 & 2.84 & 8.72 & 15.48 & 2.63 & 0.42 & 9.91 & 1.76 & 52.96 & 7.19 & 0.87 & 64.53 \\
\hline $86-3,80-82$ & 7.04 & 14.31 & 69.79 & 1.77 & 0.98 & 0.24 & 1.74 & 10.369 & 4.09 & 0.36 & 0.28 & 10.20 & 30.03 & 29.46 & 6.14 & 1.69 & 17.07 & 146.18 & 72.93 & 8.93 & 3.50 & 231.76 \\
\hline $87-4,113-115$ & 9.45 & 10.78 & 82.85 & 0.59 & 0.77 & 0.12 & 3.84 & 2.912 & 3.03 & 0.25 & 0.47 & 4.51 & 16.49 & 9.82 & 4.82 & 0.85 & 37.66 & 41.05 & 54.03 & 6.20 & 5.87 & 102.48 \\
\hline $\begin{array}{l}94-1,121-123 \\
94-2,31-33\end{array}$ & 10.68 & 7.50 & 95.60 & 0.80 & 0.27 & 0.08 & 0.88 & 0.047 & 0.45 & 0.15 & 0.19 & 0.52 & 3.39 & 13.31 & 1.69 & 0.56 & 8.63 & 0.66 & 8.02 & 3.72 & 2.37 & 11.74 \\
\hline $97-1,31-33$ & 5.10 & 16.45 & 71.36 & 0.62 & 5.03 & 0.16 & 3.13 & 1.551 & 4.88 & 0.50 & 0.15 & 12.43 & 28.45 & 10.32 & 31.50 & 1.13 & 30.70 & 21.87 & 87.02 & 12.40 & 1.87 & 282.43 \\
\hline $98-2,8-10$ & 11.14 & 11.33 & 83.75 & 0.56 & 0.79 & 0.20 & 6.23 & 0.081 & 2.32 & 0.25 & 0.46 & 4.66 & 15.55 & 9.32 & 4.95 & 1.41 & 61.10 & 1.14 & 41.37 & 6.20 & 5.75 & 105.88 \\
\hline $100-3,123-125$ & 12.24 & 7.63 & 93.22 & 0.69 & 0.39 & 0.29 & 2.29 & 0.305 & 0.61 & 0.23 & 0.13 & 0.74 & 5.68 & 11.48 & 2.44 & 2.04 & 22.46 & 4.30 & 10.88 & 5.70 & 1.62 & 16.81 \\
\hline $101-2,68-70$ & 11.69 & 7.13 & 95.31 & 0.44 & 0.29 & 0.06 & 1.81 & 0.087 & 0.40 & 0.15 & 0.10 & 0.36 & 0.70 & 7.32 & 1.82 & 0.42 & 17.75 & 1.23 & 7.13 & 3.72 & 1.25 & 8.18 \\
\hline $\begin{array}{l}114-2,145-146 \\
114-5,21-23\end{array}$ & 6.57 & 9.64 & 88.51 & 0.76 & 0.77 & 0.08 & 0.86 & 2 & 3.72 & 0.22 & 0.29 & 4.00 & 10.99 & 12.65 & 4.82 & 0.56 & 8.43 & 4.12 & 6.34 & 5.46 & 3.62 & 90.89 \\
\hline $117-5,120-122$ & 10.31 & 9.63 & 89.35 & 0.55 & 0.38 & 0.08 & 0.80 & 0.086 & 3.55 & 1.09 & 0.26 & 3.78 & 10.58 & 9.15 & 2.38 & 0.56 & 7.85 & 1.21 & 63.30 & 27.03 & 3.25 & 85.89 \\
\hline $120-3,4-6$ & 2.05 & 16.11 & 62.82 & 8.62 & 6.73 & 0.07 & 5.13 & 0.771 & 6.18 & 1.11 & 0.66 & 7.55 & 36.82 & 143.45 & 42.14 & 0.49 & 50.32 & 10.87 & 110.20 & 27.53 & 8.24 & 171.55 \\
\hline $123-3,56-64$ & 3.69 & 21.15 & 44.88 & 4.67 & 0.85 & 0.14 & 4.51 & 0.170 & 19.78 & 1.42 & 0.20 & 22.58 & 54.32 & 77.72 & 5.32 & 0.99 & 44.23 & 2.40 & 352.72 & 35.22 & 2.50 & 513.06 \\
\hline $126-6,70-80$ & 3.18 & 28.89 & 39.72 & 0.44 & 0.49 & 0.10 & 9.27 & 0.199 & 22.66 & 1.06 & 0.28 & 25.11 & 59.61 & 7.32 & 3.07 & 0.70 & 90.92 & 2.81 & 404.07 & 26.29 & 3.50 & 570.55 \\
\hline $137-1,94-98$ & 3.22 & 26.42 & 61.03 & 0.94 & 2.56 & 0.12 & 1.74 & 0.266 & 14.09 & 0.70 & 0.15 & 18.30 & 38.87 & 15.64 & 16.03 & 0.85 & 17.07 & 3.75 & 251.25 & 17.36 & 1.87 & 415.81 \\
\hline
\end{tabular}




\section{APPENDIX D}

DSDP Sample 398D-63-1, 118-120 cm (from Composite Sample 1)

Silty clay in DOM contains fine granular black detritus, black filiform inclusions, small fragments (alginite in nature), and disperse mass uniformly distributed in clay material. Bituminous components uniformly spread in a DOM occupy pore space and account for yellowish luminescence. Hydrocarbons of whitish blue luminescence coat silt grains; they are concentrated in voids of foraminifer tests. DSDP Sample 398D-73-5, 129-131 cm (from Composite Sample 2)

Claystone contains small angular fragments of plant tissue fusinized. Some fragments form micro-lenses, elongate along bedding. Some inclusions have a cutin rim of bright light yellow luminescence. Fine cutin fragments of the same bright luminescence emphasizes horizontal layering of the rock. Visually, bitumen consists of two parts, i.e., yellow and whitish blue luminescence. A part of the bitumen of yellow luminescence is uniformly scattered within a pore space of clay material and stains lenticular carbonate inclusions. Hydrocarbons of whitish blue luminescence form coatings on carbonate grains and migrate to the surface of a thin section.

DSDP Sample 398D-91-2, 113-115 cm (from Composite Sample 3)

Claystone is similar to that described above. Small open horizontal joints have hydrocarbon films of whitish blue luminescence along their walls, the content of humic DOM (detrital) is higher than in Sample 398D-75-5, 129-131 cm.

DSDP Sample 398D-96-4, 36-44 cm (from Composite Sample 3)

Claystone differs form the above sample in having better reservoir properties; there are parts with abundant inclusions of microfossils and diagonal joints. Contrary to the dense claystones, intervals where fossils are concentrated have intense blue and yellow luminescence caused by presence of bitumen. Hydrocarbons of whitish blue luminescence also were found in open joints.

DSDP Sample 398D-107-4, 92-94 cm (from Composite Sample 4)

Silty clay contains abundant fine, vitrene-like, fusainized plant detritus uniformly scattered acoss rock.
Bitumen of yellow luminescence stains carbonate clots and shows a uniform distribution in pores of clay-organic mass. Hydrocarbons of bluish white luminescence occur in open horizontal joints and form coatings on calcite grains.

DSDP Sample 398D-120-6, 18-20 cm (from Composite Sample 5)

Shows DOM distribution similar to the above sample. Bitumens may be para-autochthonous.

DSDP Sample 398D-123-3, 56-64 cm (from Composite Sample 5)

In calcareous claystone, carbonate forms small lenses of dim light yellow luminescence along bedding. Fine plant detritus (partly pyritized) is also horizontally oriented. The detritus contains black fusainized fragments some with a bright yellow cutin coating. There are many small rings without a black "core" or fragments. DOM shows a uniform distribution and is yellowish brown in ultraviolet rays. Hydrocarbons of whitish blue luminescence fill voids of foraminiferal tests. The claystone rests conformably on a bed containing debris of carbonate rocks of various origins differing in luminescence as follows: (1) Fragments of valves, brown with a thin rim, bright yellow luminescence as well as bluish white; (2) Angular debris of very bright yellow luminescence; (3) Rounded carbonate concretions of milky white luminescence; (4) Calcite after foraminiferal tests of bright blue luminescence.

In ultraviolet light, the matrix is not luminescent. In pore spaces, accumulations of hydrocarbons of whitish blue luminescence may be newly formed or para-autochthonous.

DSDP Sample 398D-138-2, 133-135 cm (from Composite Sample 6)

Clayey rock contains fine plant fusainized-like detritus. A dispersed mass together with clay forms a single organic mineral complex which is characterized by yellowish brown luminescence. Hydrocarbons of whitish bluish luminescence are concentrated in areas of microfossil remains.

Note: Lithological analysis performed by T. E. Baranova and A. S. Belikova. 

PLATE 1

Figure 1 Brecciated pelitomorphic limestone; black spots are calcareous clay clasts. Sample 398D-136-3, $125-134 \mathrm{~cm}$.

Figure 2 Mud-supported limestone conglomerate. Some limestone pebbles show composite structure implying recurrent scour. Sample 398D-124-2, 96-106 cm.

Figure 3 Turbiditic cross-laminated, fine-grained sandstone. Sample 398D-117-2, 78-96 cm. 
PLATE 1
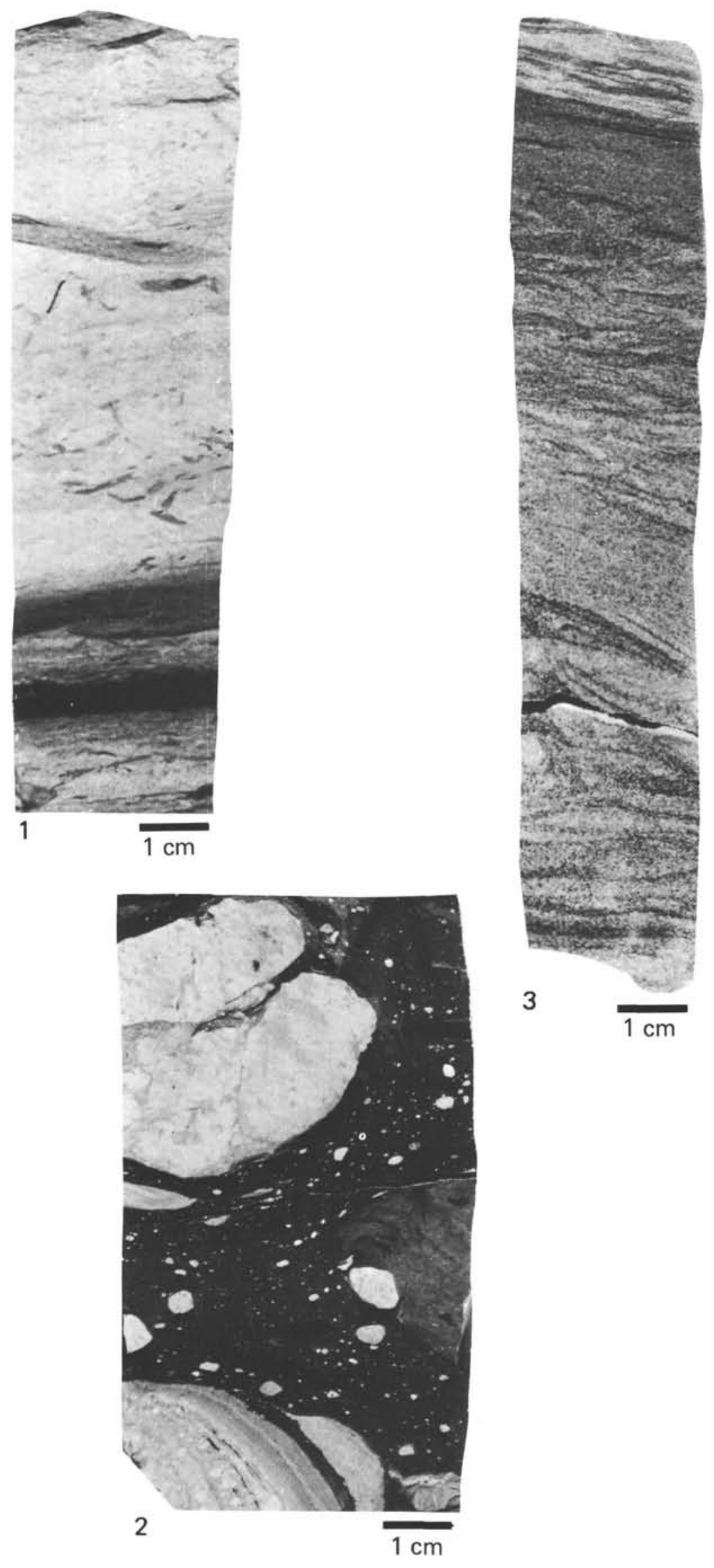


\section{PLATE 2}

Figure 1 Zeolite (clinoptilolite) crystal with radiolarian test (scanning electron micrograph of Sample $398 \mathrm{D}-65-6,38-40 \mathrm{~cm}$.)

Figure 2 Fine-grained aggregate of zeolite in clay matrix (scanning electron micrograph of Sample 398D$56-4,110-112 \mathrm{~cm})$.

Figures 3, 4 Crystalline texture of zeolite in clay matrix (scanning electron micrograph of the same sample). 
PLATE 2
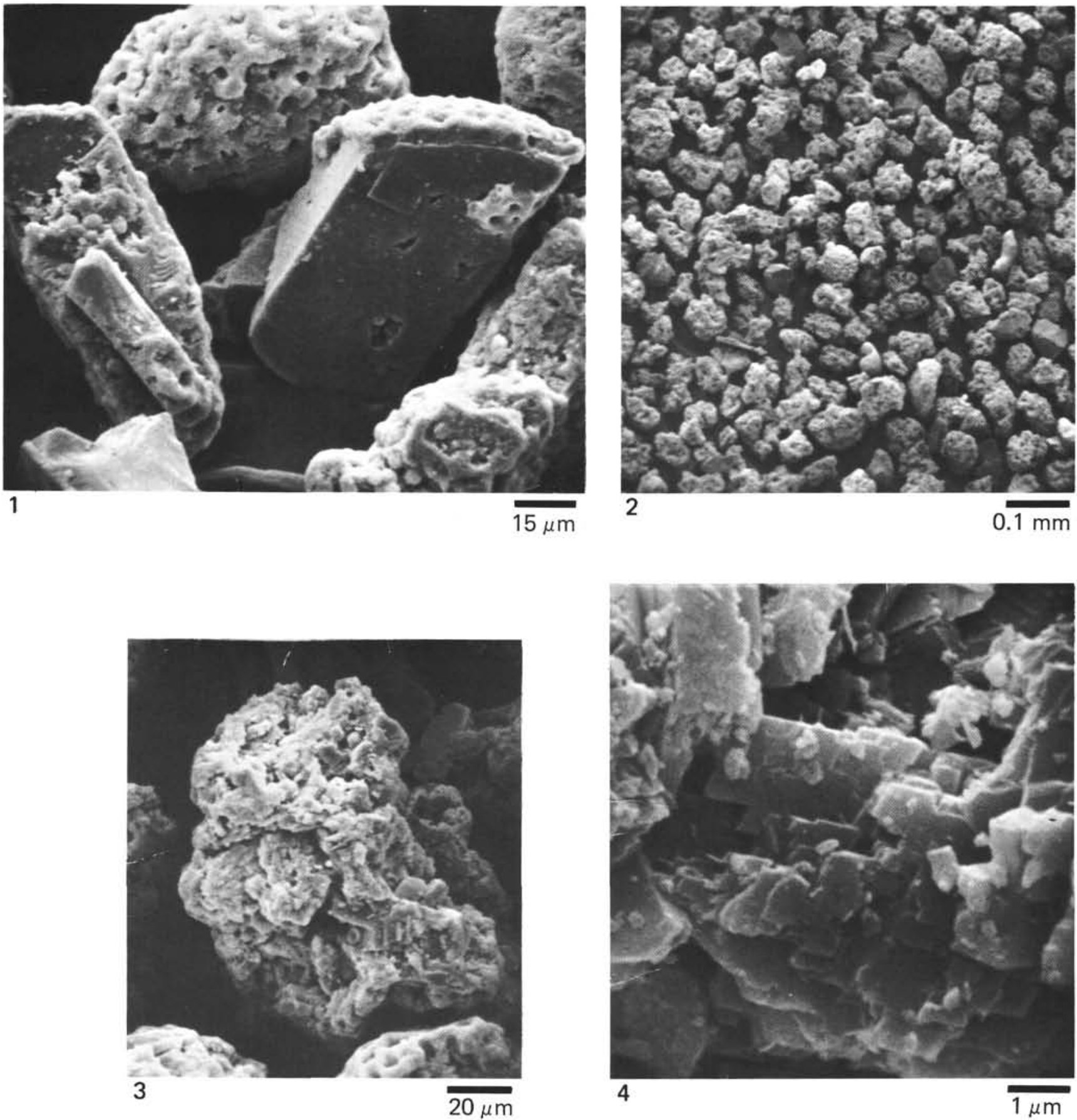


\section{PLATE 3}

Figure 1 Lamina of microcrystalline siderite in thinsection under petrographic microscope (Sample 398D-93-3, 76-78).

Figure 2 Crystalline aggregate of siderite (scanning electron micrograph of the same sample).

Figure 3 Faces of siderite crystal "entangled by very thin threads," which possibly are scraps of organic tissue (scanning electron micrograph of the same sample).

Figure $4 \quad$ Flaky overgrowths on siderite crystal faces indicating authigenic nature of siderite (scanning electron micrograph of the same sample). 
PLATE 3
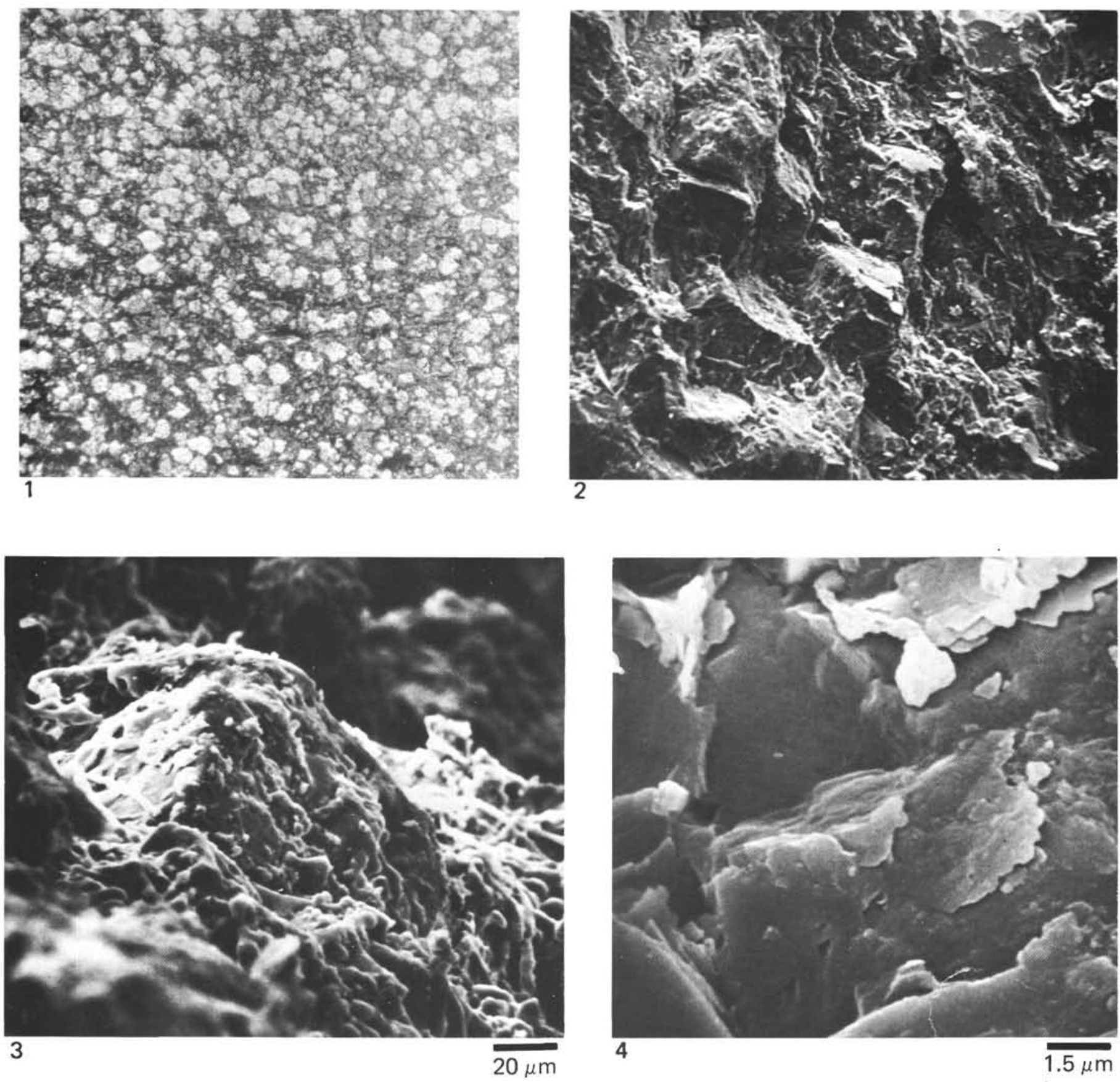


\section{PLATE 4}

Figure 1 Saccammina lathrami Tappan, Sample 398D$101-5,65-67 \mathrm{~cm}, 100 \times$.

Figures 2-4 Hyperamminoides ex gr. barksdalei Tappan. 2, 3. Sample 398D-102-4, 73-75 cm, $100 \times$.

4. Deformed specimen. Sample 398D-112-1, $89-91 \mathrm{~cm}, 100 \times$.

Figure 5 Hormosina? kijastschensis Antonova. Sample 398D-99-2, 7-9 cm, $100 \times$.

Figures 6-9 Hyperammina aptica (Dampel and Mjatliuk). 6, 7. Sample 398D-114-1, 127-129 cm, $100 \times$. 8 , 9. Sample 398D-117-5, $21-23 \mathrm{~cm}, 100 \times$.

Figure 10 Glomospira corona Cushman and Jarvis, Sample 398D-111-1, 139-141 cm, $100 \times$.

Figures 11, 12 Ammodiscus cretaceous (Reuss), Sample 398D$101-5,65-67 \mathrm{~cm}, 100 \times$.

Figures 13, 18 Bathysiphon? sp., Sample 398D-112-1, 89-91 $\mathrm{cm}, 100 \times$.

Figures 14-16 Haplophragmoides concavus Chapman.

14, 15. Sample 398D-98-1, 87-89 cm, $100 \times$.

16. Sample 398D-100-4, $97-99 \mathrm{~cm}, 100 \times$.

Figures 17, 21 Glomospirella chapmani Mjatliuk.

17. Sample 398D-113-1, $41-43 \mathrm{~cm}, 100 \times$.

21. Sample 398D-101-1, 77-79 cm, $100 \times$.

Figures 19, 20 Trochammina (?) glomerata Antonova. Sample 398D-101-1, 77-79 cm, $100 \times$. 


\section{PLATE 4}
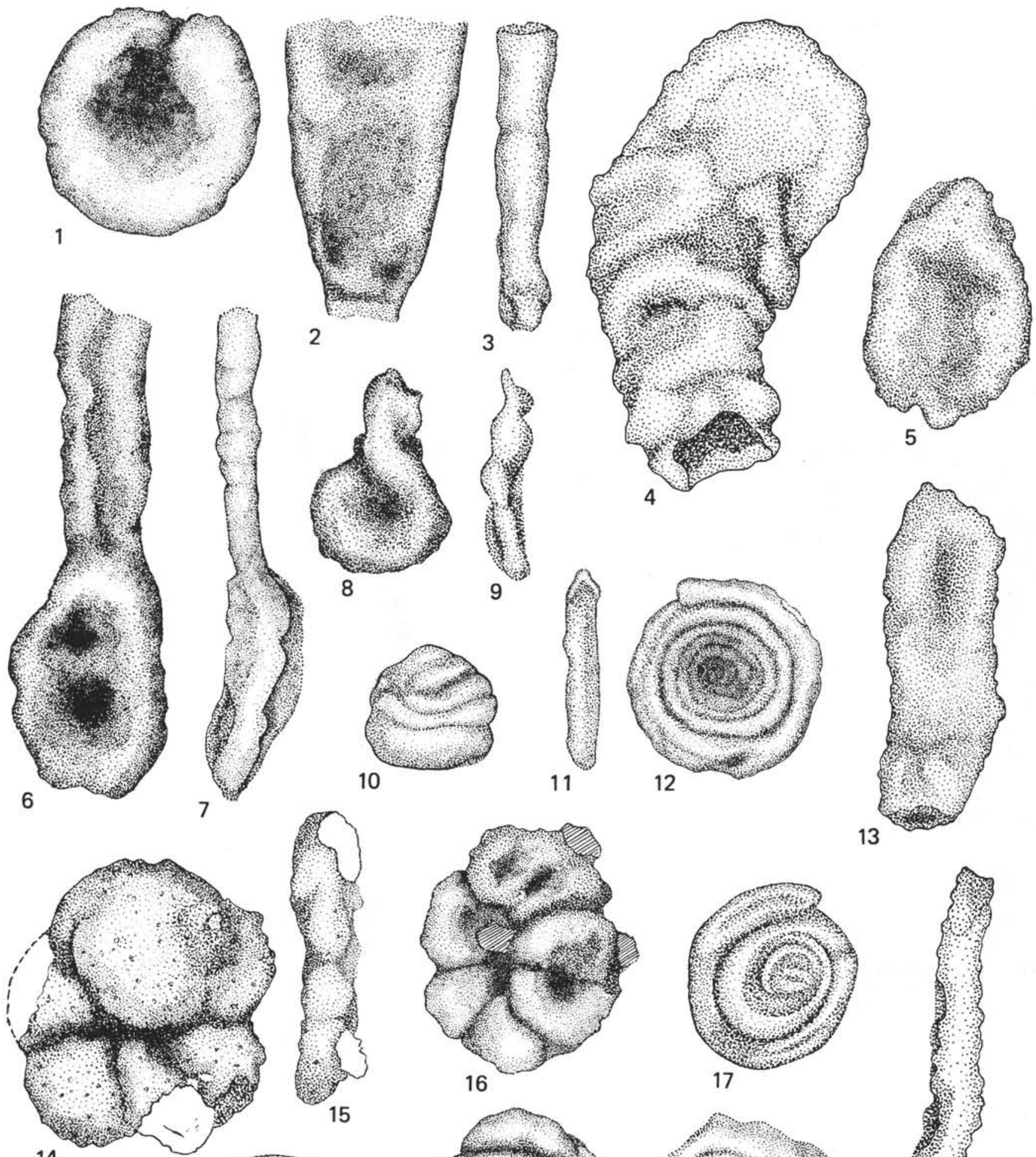

14
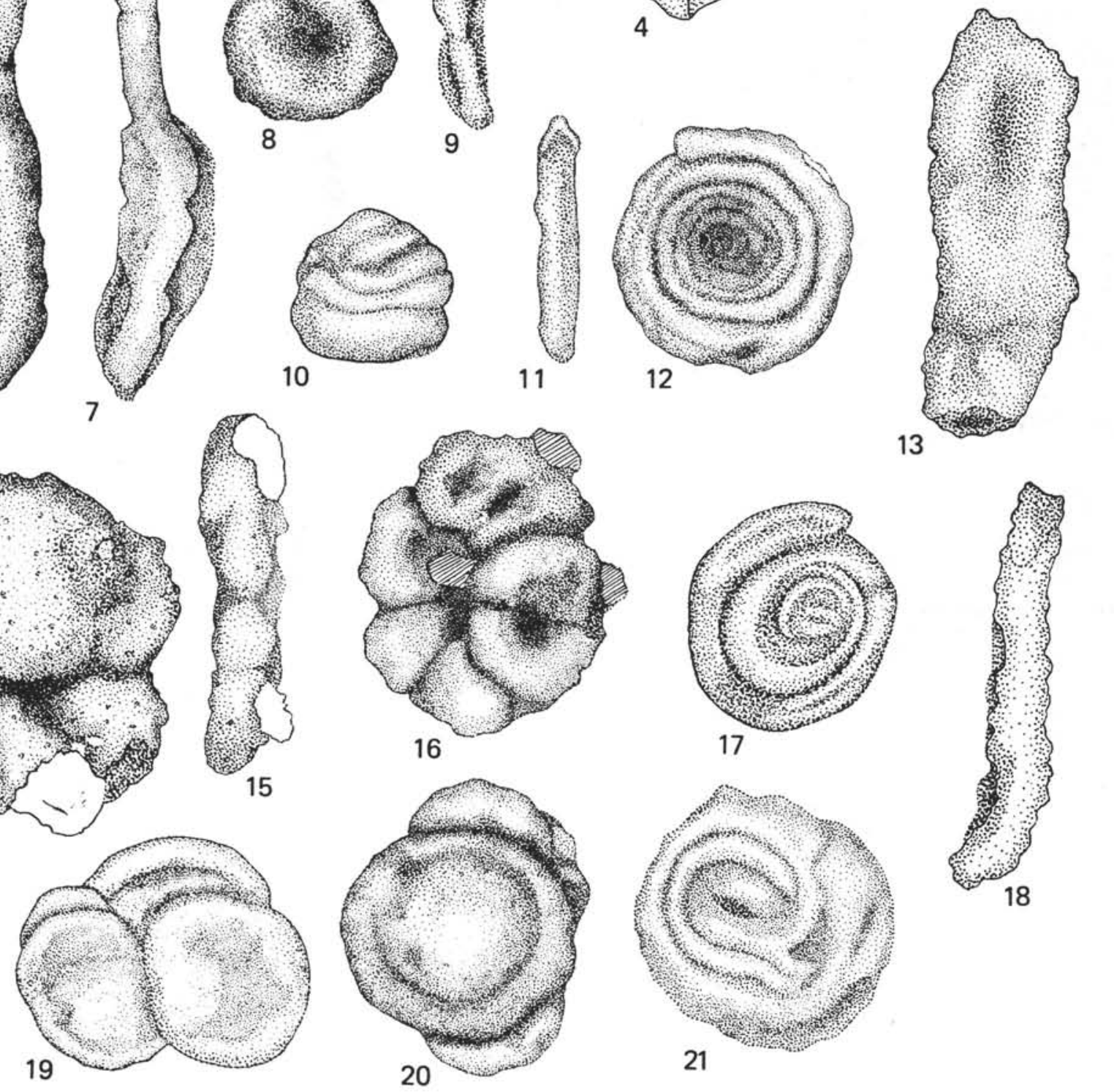


\section{PLATE 5}

Figures 1, 2 Pseudonodosaria sp.n. Sample 398D-122-4, $132-134 \mathrm{~cm}, 85 \times, 75 \times$.

Figure 3 Pseudonodosaria humilis (Roemer). Sample 398D-122-4, 132-134 cm, $55 \times$.

Figure 4 Pseudonodosaria appressa (Loeblich and Tappan). Sample 398D-122-4, 132-134, $55 \times$.

Figures 5-6 Marginulina cephalotes Reuss. Sample 398D-103-2, 38-70 cm, $50 \times$.

Figure $7 \quad$ Lingulina? sp. Probably microspheric generation of Lingulina loryi with curved initial part. Sample $398 \mathrm{D}-104-4,21-23 \mathrm{~cm}, 80 \times$.

Figures 8, 9 Lingulina loryi Berthelin. Sample 398D-86-2, 15-17, $90 \times$.

Figure 10 Lingulina buddencanyonensis Dailey. Sample 398D-104-4, 21-23 cm, $80 \times$.

Figures 11, 12 Pleurostomella obtusa Berthelin. Sample 398D$66-1,132-134 \mathrm{~cm}, 95 \times$.

Figures 13, 17 Eponides? wassoewici Djaffarov and Agalarova. Sample 398D-86-2, 15-17 cm, $93 \times, 130 \times$.

Figures 14, 18 Gavelinella suturalis (Mjatliuk). Sample 398D$104-2,18-20 \mathrm{~cm}, 70 \times$.

Figure 15 Lenticulina nodosa (Reuss). Sample 398D-122-4, $132-134 \mathrm{~cm}, 50 \times$.

Figure 16 Pleurostomella subbotinae Djaffarov and Agalarova. Sample 398D-62-4, 3-5 cm, $95 \times$.

Figure 19 Nodosaria concinna Reuss. Sample 398D-103-2, $38-70 \mathrm{~cm}, 53 \times$.

Figure 20 Pleurostomella mirabilis Bukalova. Sample 398D-68-3, 145-147 cm, $95 \times$.

Figure $21 \quad$ Pleurostomella obtusa Berthelin. Sample 398D-106-2, 81-83 cm, $95 \times$.

Figure 22 Pleurostomella copiosa Bukalova. Sample 398D-67-3, 133-135 cm, $95 \times$.

Figures 23, 24 Pleurostomella subnodosa Reuss.

23. Sample 398D-62-3, 34-36 cm, $95 \times$.

24. Sample 398D-63-4, 3-5 cm, $95 \times$. 


\section{PLATE 5}

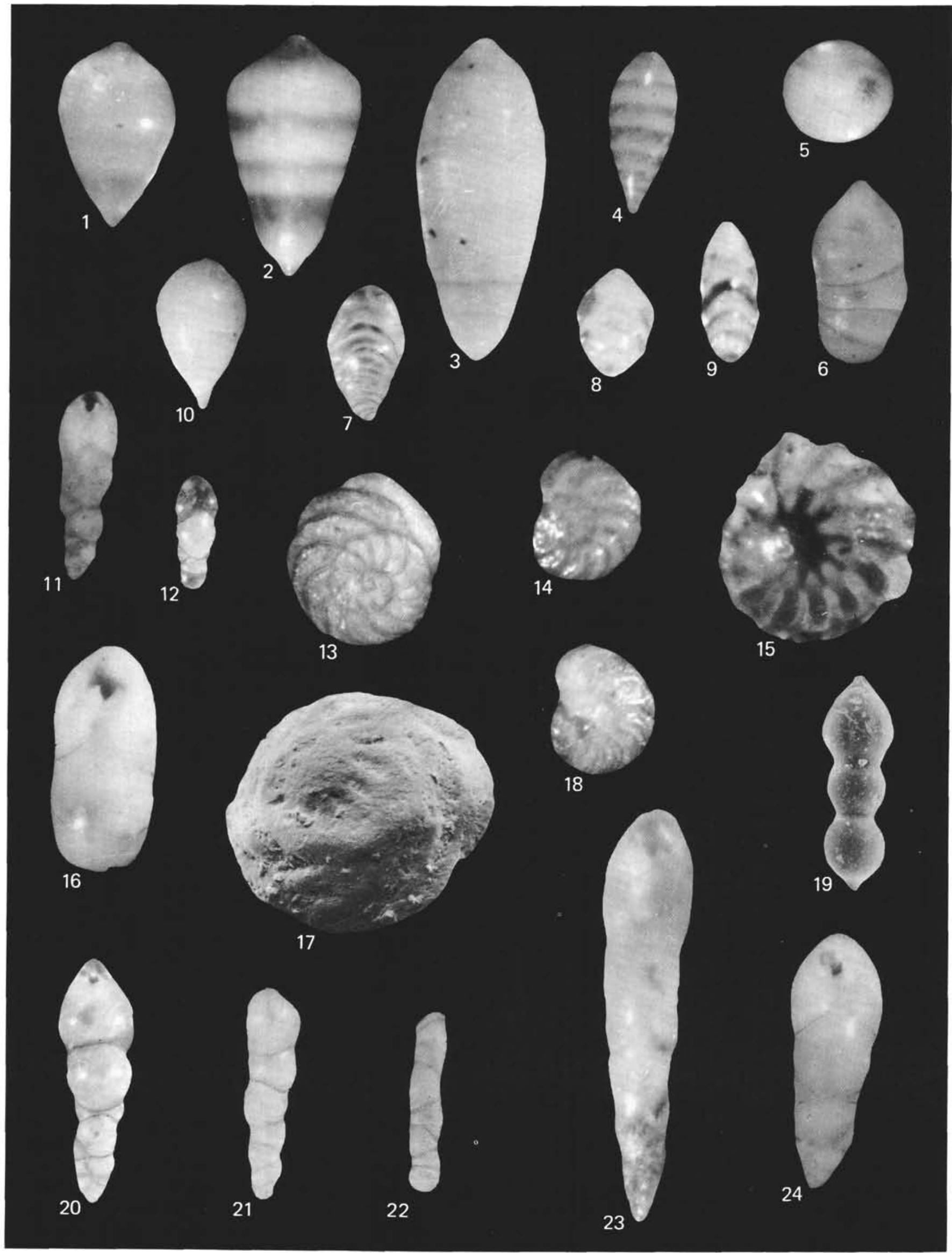




\section{PLATE 6}

Figure 1 Verneuilina pyramidata Tairov. Sample 398D$72-3,65-67 \mathrm{~cm}, 150 \times$.

Figure 2 Saracenaria spinosa (Ehrenberg). Sample 398D$106-2,150 \times$.

Figures 3, 5 Gyroidinoides infracretaceous (Morozova).

3. Sample 398D-77-2, 54-56 cm, $90 \times$.

5. Sample $398 \mathrm{D}-82-2,148-150 \mathrm{~cm}, 150 \times$.

Figure 4 Gyroidinoides(?) mjatliukae (Antonova). Sample 398D-103-6, 80-82 cm, $200 \times$.

Figure 6 Gyroidinoides(?) paleovortex (Djaffarov and Agalarova). Sample 398D-86-2, $15-17 \mathrm{~cm}, 150 \times$.

Figures 7, 8 Lingulogavelinella sp. Sample 398D-103-2, 38-70 $\mathrm{cm}, 150 \times, 75 \times$.

Figures 9, 10 Gyroidinoides infracretaceous (Morozova).

9. Sample 398D-103-6, 80-82 cm, $150 \times$.

10. Sample 398D-86-2, $15-17 \mathrm{~cm}, 200 \times$.

Figure 11 Osangularia sp. Sample 398D-62-2, 138-140 cm, $90 \times$.

Figure 12 Baggina(?) sp. Sample 398D-75-3, 134-136 cm, $300 \times$.

Figures 13, 15, Osangularia infracretacea (Bukalova). Sample 16 398D-86-1, 138-140 cm, $150 \times$. 
PLATE 6

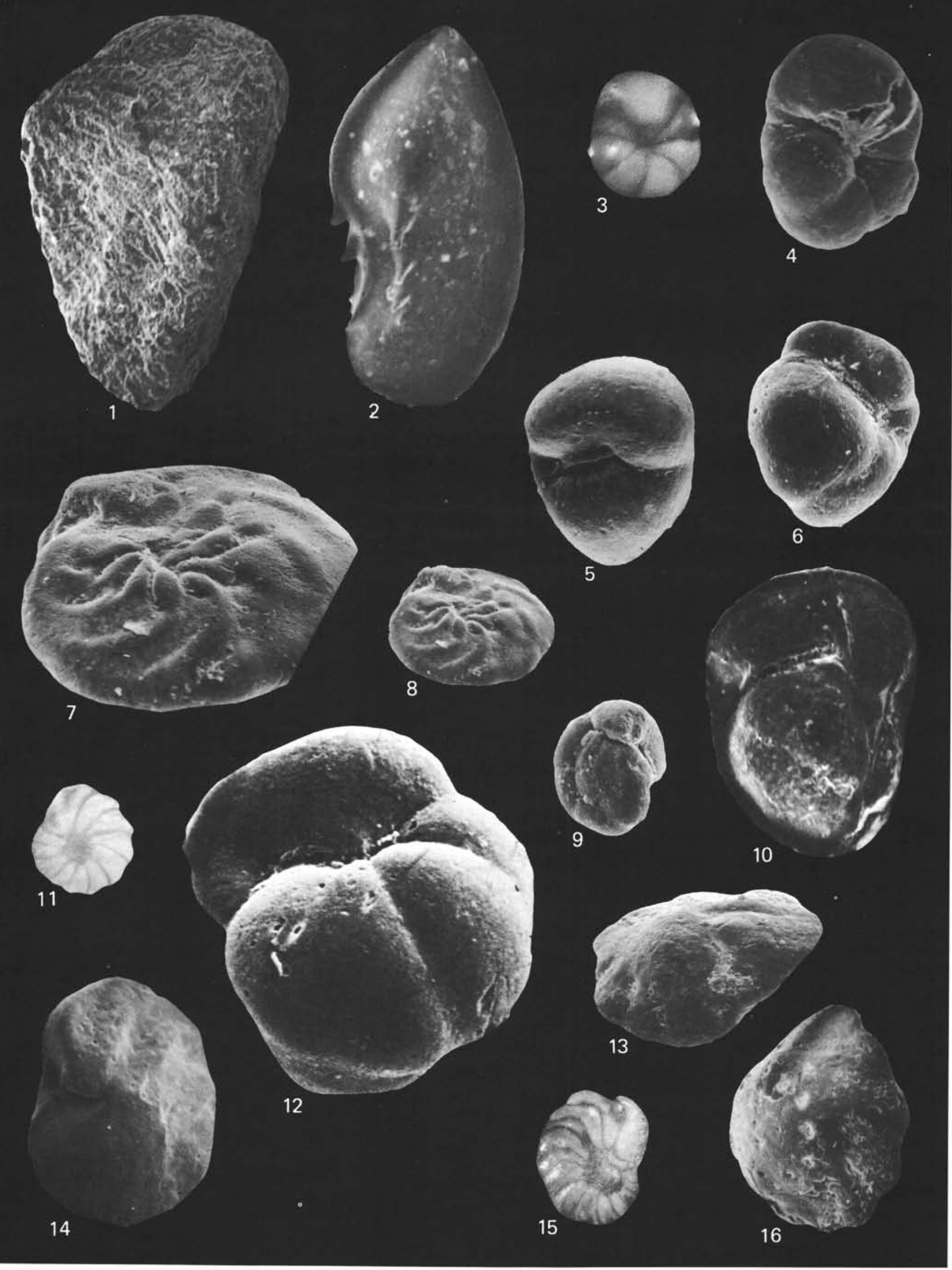

